\title{
Bile Acid-Gut Microbiota Axis in Inflammatory Bowel Disease: From Bench to Bedside
}

\author{
Min Yang ${ }^{1,+} \mathbb{D}$, Yu Gu ${ }^{1,+}$, Lingfeng Li ${ }^{1}$, Tianyu Liu ${ }^{1}$, Xueli Song ${ }^{1}$, Yue Sun ${ }^{1}$, Xiaocang Cao ${ }^{1}$, Bangmao Wang ${ }^{1}$, \\ Kui Jiang ${ }^{2, *}$ and Hailong Cao ${ }^{1, *(\mathbb{D})}$
}

1 Department of Gastroenterology and Hepatology, Tianjin Institute of Digestive Diseases, Tianjin Key Laboratory of Digestive Diseases, Tianjin Medical University General Hospital, Tianjin 300052, China; yangmin@tmu.edu.cn (M.Y.); guyu@tmu.edu.cn (Y.G.); lilingfeng0419@tmu.edu.cn (L.L.); liutianyu@tmu.edu.cn (T.L.); songxueli@tmu.edu.cn (X.S.); sun_yue@tmu.edu.cn (Y.S.); doccaoxc@163.com (X.C.); mwang02@tmu.edu.cn (B.W.)

2 Graduate School of Tianjin Medical University, Tianjin 300070, China

* Correspondence: kjiang@tmu.edu.cn (K.J.); caohailong@tmu.edu.cn (H.C.)

+ These authors have contributed equally to this work.

Citation: Yang, M.; Gu, Y.; Li, L.; Liu, T.; Song, X.; Sun, Y.; Cao, X.; Wang, B.; Jiang, K.; Cao, H. Bile Acid-Gut Microbiota Axis in Inflammatory Bowel Disease: From Bench to Bedside. Nutrients 2021, 13, 3143. https://doi.org/10.3390/nu13093143

Academic Editors: Giulia Roda and Stefania Vetrano

Received: 1 August 2021

Accepted: 30 August 2021

Published: 9 September 2021

Publisher's Note: MDPI stays neutral with regard to jurisdictional claims in published maps and institutional affiliations.

Copyright: (C) 2021 by the authors. Licensee MDPI, Basel, Switzerland. This article is an open access article distributed under the terms and conditions of the Creative Commons Attribution (CC BY) license (https:/ / creativecommons.org/licenses/by/ $4.0 /)$.

\begin{abstract}
Inflammatory bowel disease (IBD) is a chronic, relapsing inflammatory disorder of the gastrointestinal tract, with increasing prevalence, and its pathogenesis remains unclear. Accumulating evidence suggested that gut microbiota and bile acids play pivotal roles in intestinal homeostasis and inflammation. Patients with IBD exhibit decreased microbial diversity and abnormal microbial composition marked by the depletion of phylum Firmicutes (including bacteria involved in bile acid metabolism) and the enrichment of phylum Proteobacteria. Dysbiosis leads to blocked bile acid transformation. Thus, the concentration of primary and conjugated bile acids is elevated at the expense of secondary bile acids in IBD. In turn, bile acids could modulate the microbial community. Gut dysbiosis and disturbed bile acids impair the gut barrier and immunity. Several therapies, such as diets, probiotics, prebiotics, engineered bacteria, fecal microbiota transplantation and ursodeoxycholic acid, may alleviate IBD by restoring gut microbiota and bile acids. Thus, the bile acid-gut microbiota axis is closely connected with IBD pathogenesis. Regulation of this axis may be a novel option for treating IBD.
\end{abstract}

Keywords: inflammatory bowel disease; gut microbiota; bile acids; bile acid-activated receptors; therapy

\section{Introduction}

Inflammatory bowel disease (IBD) is a cluster of chronic and relapsing gastrointestinal inflammatory conditions, the dominating subtypes of which are ulcerative colitis (UC) and Crohn's disease (CD). IBD has aroused wide attention for its increasing incidence and prevalence worldwide [1]. In addition, IBD is prone to recurrence and persistence and patients with IBD have an increased risk of colorectal cancer [2]. As a multifactorial disease, the precise aetiology and pathogenesis of IBD are complex and remain unestablished. Genetic susceptibility, environmental factors (e.g., diet, smoking and antibiotics), gut dysbiosis and host immune response have been reported to be closely associated with IBD pathogenesis [3]. Changes in environmental factors and gut microbiota likely account for the spread of IBD globally [4].

Trillions of microbes inhabited in human gut are involved in various biological metabolisms and immune processes in the host. Gut microbiota has essential roles in maintaining intestinal homeostasis and disturbance of the microbial community emerges as a key factor for the occurrence and progression of IBD [5]. The regulatory functions of gut microbiota are principally based on the abundant microbial metabolites of dietary substrates, such as bile acids and short-chain fatty acids (SCFAs). Bile acids are the metabolic products of dietary substrates; they play a vital role in metabolism and immunological 
regulation [6,7]. Primary bile acids are synthesized from cholesterol in the liver and then transported to the intestine, where they are converted into secondary bile acids by some specific bacterial species (e.g., Clostridium and Eubacterium) [8]. Bile acids could bind with bile acid-activated receptors and exert regulatory effects. These receptors include farnesoid $X$ receptor (FXR), Takeda G-protein receptor 5 (TGR5), pregnane $X$ receptor (PXR) and vitamin D receptor (VDR). Abnormal bile acid metabolism has been reported in patients with IBD and interactions between bile acids and gut microbiota have been emphasized in the pathogenesis of IBD [9-12].

The present review concentrated on discussing the complex interactions between bile acids and gut microbiota in IBD and summarized the potential therapeutic approaches targeting the bile acid-gut microbiota axis for IBD.

\section{Bile Acid-Gut Microbiota Axis in IBD}

Bile acids and gut microbiota have bidirectional effects on each other. Gut microbiota is engaged in the synthesis and transformation of bile acids, (Figure 1) which could affect the microbial composition. Dysregulation of bile acids or bile-acid activated receptors cooperates with gut dysbiosis to cause intestinal inflammation (Figure 2).

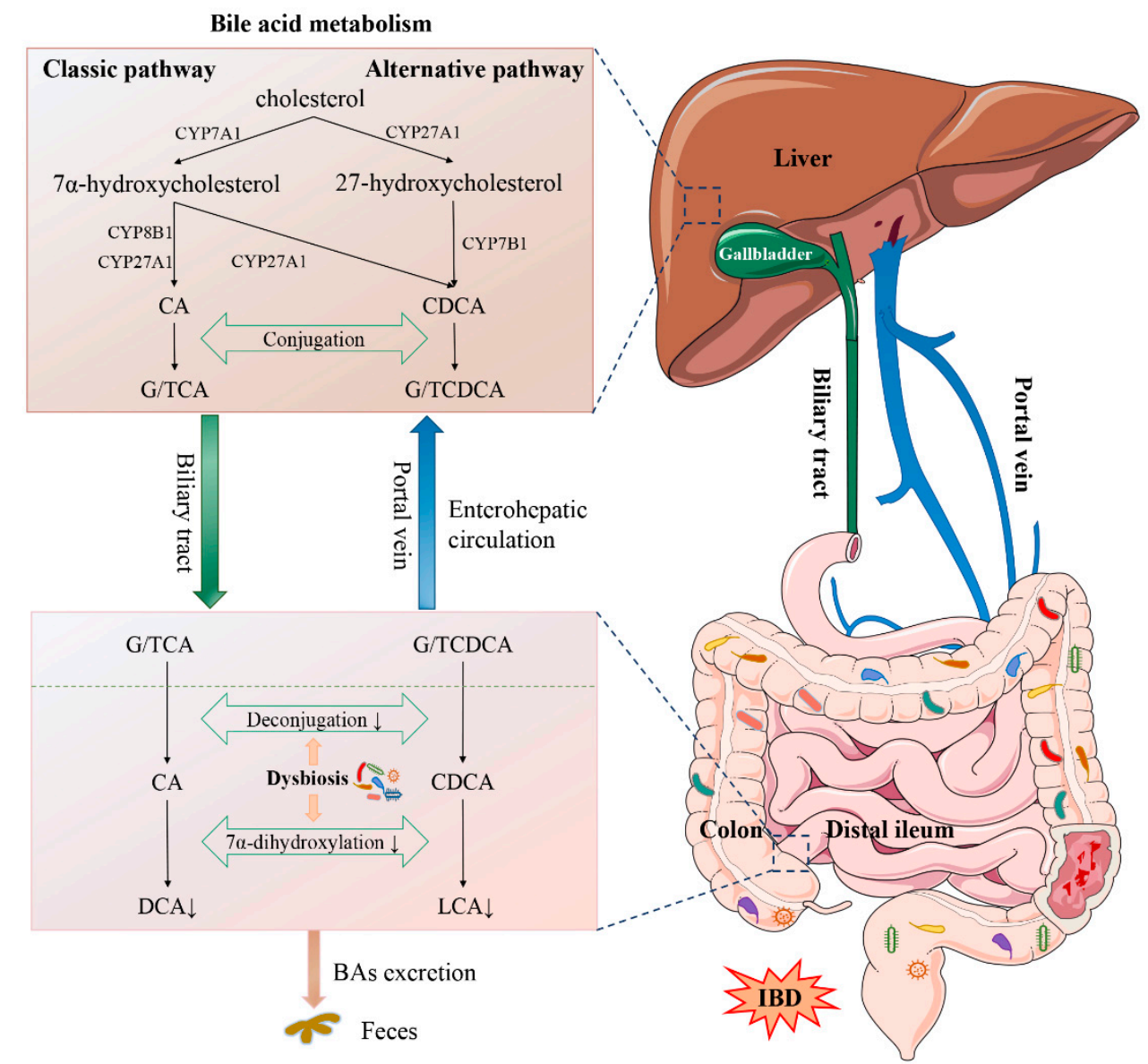

Figure 1. Bile acid synthesis and metabolism and the major changes in IBD. Abbreviations: IBD, inflammatory bowel disease; CA, cholic acid; CDCA, chenodeoxycholic acid; GCA, glycocholic acid; TCA, taurocholic acid; GCDCA, glycochenodeoxycholic acid; TCDCA, taurochenodeoxycholic acid; DCA, deoxycholic acid; LCA, lithocholic acid; BA, bile acid; CYP7A1, cholesterol-7 $\alpha$-hydroxylase; CYP27A1, mitochondrial sterol-27-hydroxylase; CYP8B1, sterol-12 $\alpha$-hydroxylase; CYP7B1, oxysterol $7 \alpha$-hydroxylase. 


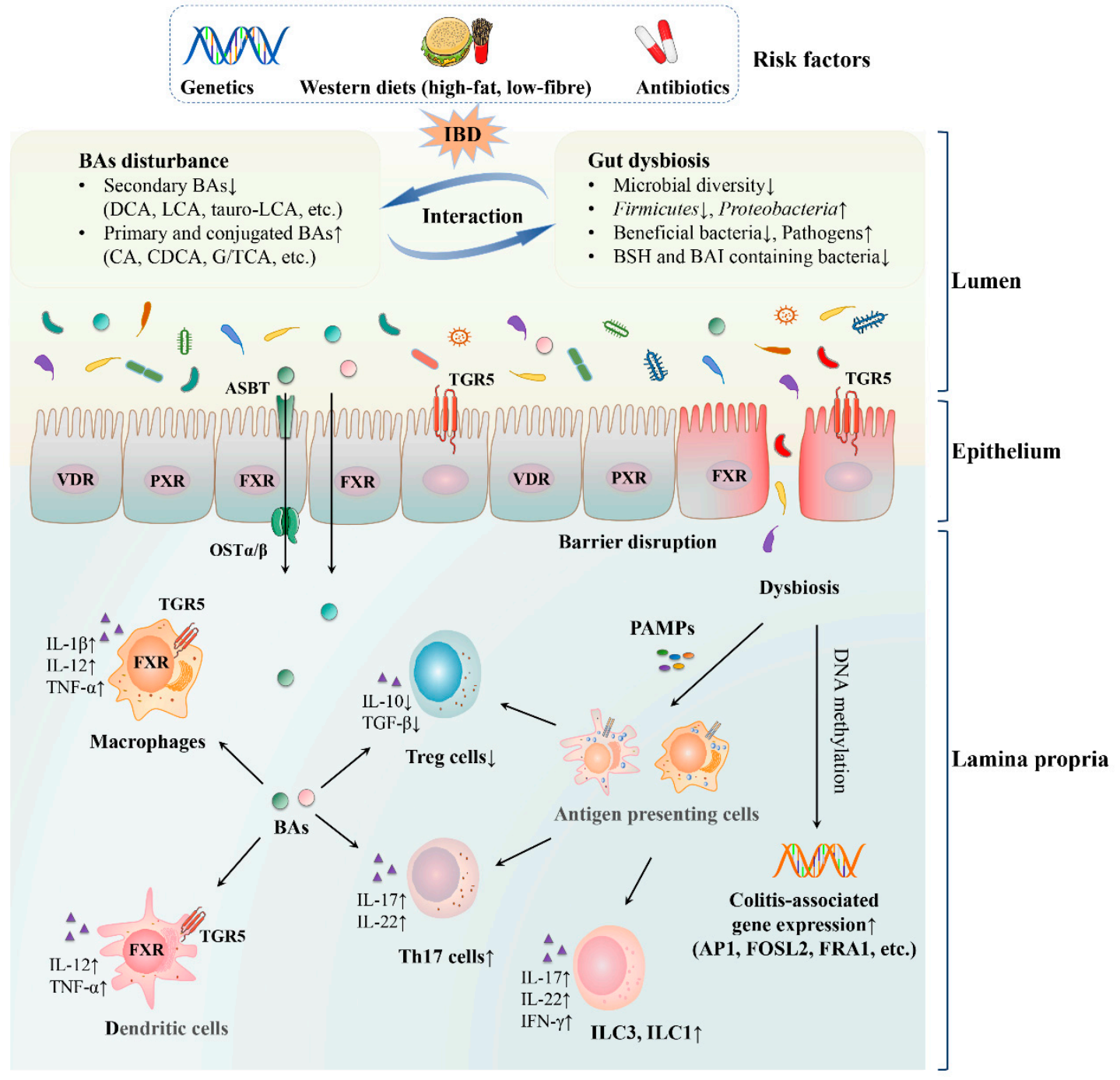

Figure 2. Bile acid-gut microbiota axis in IBD. Abbreviations: DCA, deoxycholic acid; LCA, lithocholic acid; CA, cholic acid; CDCA, chenodeoxycholic acid; GCA, glycocholic acid; TCA, taurocholic acid; FXR, farnesoid X receptor; TGR5, Takeda G-protein receptor 5; PXR, pregnane X receptor; VDR, vitamin D receptor; $\mathrm{BSH}$, bile salt hydrolase; $\mathrm{BAI}$, bile acid-inducible enzymes; IBD, inflammatory bowel disease; PAMPs, pathogen-associated molecular patterns; ASBT, apical sodium-dependent bile acid transporter; $\operatorname{OST} \alpha / \beta$, organic solute transporter subunit $\alpha / \beta$; Th17 cells, T helper 17 cells; Treg cells, regulatory T cells; ILC3, group 3 innate lymphoid cells; ILC1, group 1 innate lymphoid cells; IL-1 $\beta$, interleukin-1 $\beta$; IL-10, interleukin-10; IL-12, interleukin-12; IL-17, interleukin-17; IL-22, interleukin-22; TNF- $\alpha$, tumor necrosis factor- $\alpha$; TGF- $\beta$, transforming growth factor- $\beta$; IFN- $\gamma$, interferon- $\gamma$.

Primary BAs (CA and CDCA) are synthesized in the liver and then conjugated to glycine or taurine to form into conjugated BAs (G/TCA and G/TCDCA), respectively. They are stored in the gallbladder and excreted into the intestine to be further metabolized by gut microbiota postprandially. In the terminal ileum, most conjugated BAs are reabsorbed and the others go through the deconjugation mediated by colonic microbiota. In colon, the unconjugated BAs are further transformed into secondary BAs (DCA and LCA) via $7 \alpha-$ dehydroxylation and finally excreted in feces. In IBD, gut dysbiosis affects the metabolism and mainly reduces the deconjugation and $7 \alpha$-dehydroxylation, leading to the depletion of secondary BAs.

Multiple risk factors (e.g., genetics, western diets and antibiotics) could cause gut dysbiosis and BA perturbations and they are associated with IBD pathogenesis. Under IBD conditions, the microbial diversity is reduced remarkably, with a decreased level of Firmicutes and an increased level of Proteobacteria. Beneficial bacteria are reduced, whereas 
pathogens are increased. Most importantly, the abundance of BSH and BAI containing bacteria, such as Ruminococcaceae, Lachnospiraceae and Eubacterium declines. Secondary BAs (such as DCA, LCA and tauro-LCA) are decreased, whilst primary and conjugated BAs (such as CA, CDCA and G/TCA) are elevated because of impaired transformation induced by gut dysbiosis. In turn, disturbed BA profile influences the microbial composition. Moreover, absence or inactivation of BA-activated receptors FXR, TGR5, PXR and VDR disrupts intestinal barrier and incurs bacterial translocation. Afterwards, the dysbiosis could modify colitis-associated gene expression by reprogramming DNA methylation. BAs could be transported by ASBT and OST $\alpha / \beta$ receptors or passively diffused across the enterocytes and interact with mucosal immune cells. The disturbed gut microbiota and BA profile, especially the reduced secondary BAs, could influence gut immunity, including breaking the balance between Th17 and Treg cells and increasing ILC 3 and ILC1 differentiation. Furthermore, inactivation or absence of FXR and TGR5 in macrophages and dendritic cells increases the production of pro-inflammatory cytokines.

\subsection{Gut Dysbiosis in IBD}

A recent review comprehensively summarized the evidence for the vital role of gut microbiota in IBD, including multiple human and animal studies [13]. Although no specific microbiota is consistently associated with IBD because of different populations, samples and detection methods, the overall trends of gut dysbiosis are consistent. Most studies have revealed reduced microbiome biodiversity in patients with IBD. Meanwhile, the microbial composition is altered, characterized by the reduction in phylum Firmicutes and the enrichment of phylum Proteobacteria. Beneficial bacteria are decreased, whilst pathogens including Escherichia coli are increased. These are the most common microbial characteristics of patients with IBD. But there are some differences between patients with CD and UC. The dysbiosis of $C D$ is much greater than that of $U C$, with lower diversity and greater changes in composition [14-16]. In patients with CD, the abundance of Erysipelotrichales, Bacteroidales and Clostridiales, Ruminococcaceae and Lachnospiraceae families and Faecalibacterium prausnitzii was reduced, whereas that of Enterobacteriaceae, such as E. coli, Pasteurellacaea, Veillonellaceae, and Fusobacteriaceae families, was elevated [14,17-19]. In patients with UC, reductions in Clostridium XIVa, Butyricicoccus, Eubacterium rectale, F. prausnitzii and Roseburia hominis of the Ruminococcaceae and Lachnospiraceae families were found, whilst Ruminococcus gnavus, Clostridium ramosum and E. coli were enriched [20-22]. Intriguingly, some beneficial bacteria, such as F. prausnitzii and R. hominis, are SCFA-producing bacteria and they play vital roles in bile acid metabolism.

Gut dysbiosis may participate in the pathogenesis of IBD mainly through the following mechanisms. Ansari et al. [23] found that the gut microbiota under acute inflammatory conditions could modify the host gene expression by reprogramming DNA methylation, leading to upregulation of colitis-associated gene expression (such as AP1, FOSL2 and FRA1). Besides, the dysbiosis in IBD, especially the reduction in SCFA-producing bacteria, leads to decreased production of SCFAs (such as acetate, propionate and butyrate). SCFAs are important energy sources of intestinal epithelium and devoted to strengthening the intestinal barrier function [24]. They also induce the differentiation of regulatory $\mathrm{T}$ (Treg) cells and maintain the immune homeostasis [25]. Thus, the reduction of SCFAs in IBD results in impaired barrier and reduced Treg cells. Furthermore, gut microbiota could regulate intestinal immunity. On the one hand, gut microbiota has the property of shaping intestinal innate lymphoid cells (ILCs) [26]. In IBD, macrophages respond to the gut microbiota and lead to the activation of ILC 3 and dendritic cells promote the differentiation from ILC3 toward ILC1 $[27,28]$. The dysregulation of ILC3 and ILC1 leads to elevated production of pro-inflammatory cytokines interleukin-22 (IL-22), IL-17 and interferon- $\gamma$ $($ IFN- $\gamma)$ [29]. On the other hand, gut microbiota is implicated in the modulation of adaptive immunity. The microbiota from patients with IBD could induce intestinal immune disorders in sterile mice, as manifested by increased Thelper 17 (Th17) cells with pro-inflammatory cytokines (e.g., IL-17 and IL-22) and reduced Treg cells with anti-inflammatory cytokines, 
such as IL-10 and transforming growth factor- $\beta$ (TGF- $\beta$ ) $[30,31]$. Intriguingly, Devkota et al. found that the pathogen Bilophila wadsworthia was associated with colitis in $I L^{10-/-}$ mice [32]. B. wadsworthia bloomed following the increase in taurine-conjugated bile acids, leading to activated dendritic cells and subsequent Th1-mediated colitis. The present study suggested that the crosstalk of bile acids and gut microbiota may be implicated in the pathogenesis of IBD.

\subsection{Bile Acid Synthesis and Metabolism}

Primary bile acids, which are synthesized in the hepatocytes, consist of cholic acid (CA) and chenodeoxycholic acid (CDCA) in humans. The synthetic process involves a series of complex enzymatic reactions via two pathways initiated by cholesterol $7 \alpha$-hydroxylase (CYP7A1) and sterol-27-hydroxylase (CYP27A1). Subsequently, primary bile acids are conjugated to glycine or taurine and then excreted into the intestine. In the distal ileum, approximately $95 \%$ of these bile acids undergo enterohepatic circulation through apical sodium-dependent bile acid transporter (ASBT) and organic solute transporter subunit $\alpha / \beta(\mathrm{OST} \alpha / \beta)$. The remaining bile acids are further metabolized by the colonic microbiota. Conjugated bile acids mainly go through deconjugation, followed by $7 \alpha$-dehydroxylation and epimerization via gut microbiota, and converted to secondary bile acids, namely deoxycholic acid (DCA), lithocholic acid (LCA) and ursodeoxycholic acid (UDCA). These bile acids are either passively reabsorbed in the colon or excreted in the feces [33] (Figure 1).

\subsection{Microbial Modulation of Bile Acid Synthesis and Metabolism}

Gut microbiota could regulate liver enzymes CYP7A1 and CYP27A1, thereby affecting bile acids [34]. More importantly, gut microbiota participates in the biotransformation of bile acids via microbial enzymes. Conjugated bile acids go through hydrolysis mediated by bile salt hydrolase (BSH) and they are transformed into unconjugated bile acids. BSH has been identified in extensive bacterial genera, including Lactobacillus, Bifidobacterium, Clostridium, Bacteroides and Enterococcus [35]. Besides, the conversion of secondary bile acids is attributed to limited bacteria with bile acid-inducible enzymes (BAIs), including Clostridium cluster XIVa (e.g., Lachnospiraceae and Ruminococcaceae) and Eubacterium in phylum Firmicutes [36]. Therefore, bile acid synthesis and metabolism are regulated by gut microbiota to a large extent.

Duboc et al. found that Clostridium coccoides, Clostridium leptum and F. prausnitzii were reduced remarkably in patients with IBD in remission and flare. Lactobacillus and Enterobacteria (E. coli at a species level) were increased in flare. Compared with healthy subjects, patients with IBD, especially active IBD, showed decreased ratios of F. prausnitzii and E. coli. Clostridium and F. prausnitzii are well known to support deconjugation and transformation activities. In the present study, the gut microbiota of patients with IBD also exhibited an impaired ability to deconjugate and transform bile acids. The proportion of conjugated bile acids in feces increased, whilst that of secondary bile acids decreased. In addition, impairment of microbial de-sulphation capability with a high level of 3-OHsulphated bile acids was reported in IBD [9]. Sinha et al. explored the microbiota and bile acids in UC and familial adenomatous polyposis (FAP) and found that Ruminococcaceae, one of the bacteria producing secondary bile acids, was decreased considerably in UC. Stool microbial genomes also showed a decreased expression of BAI genes. Bile acid profile showed remarkably reduced secondary bile acids (LCA and DCA) and increased CDCA in UC. The level of CA also increased but not significant. Furthermore, the microbiota in feces from UC remarkably reduced the production of LCA and DCA in vitro compared with that from FAP. This experiment highlighted the loss of microbial metabolism in UC [10]. Other studies also found that phylum Firmicutes (e.g., Clostridium and F. prausnitzii) was remarkably reduced in patients with IBD [15,16,18,19,37-39] (The major changes of gut microbiota and bile acids were listed in Table 1) and genomic analysis hinted the depletion of bile acid biotransformation capabilities and production potential in microbiota in IBD $[40,41]$. Consistently, the concentration of secondary bile acids (particularly LCA 
and DCA) decreased substantially, whereas the proportion of primary and conjugated bile acids was elevated. Recently, Yang et al. investigated the differences of bile acids and gut microbiota between patients with UC and healthy controls and analyzed the relationships of bile acids and microbiota. The main conclusions were consistent with previous studies. They found that the secondary bile acids, such as LCA, DCA and tauro-LCA were reduced significantly in UC compared with healthy controls and were positively related to Faecalibacterium, Roseburia, Butyricicoccus and Clostridium. The primary and conjugated bile acids (CA, TCA and G/TCDCA) were elevated and were positively correlated with Enterococcus, Klebsiella and Streptococcus [22].

Table 1. Changes in Gut Microbiota and Bile Acids Profile in Patients with Inflammatory Bowel Disease.

\begin{tabular}{|c|c|c|c|}
\hline Publication & Patients & Samples and Methods & Major Findings \\
\hline $\begin{array}{l}\text { Duboc et al., } \\
2013 \text { [9] }\end{array}$ & $\begin{array}{l}12 \text { with CD, } 30 \text { with } \\
\text { UC and } 29 \mathrm{HCs}\end{array}$ & $\begin{array}{l}\text { Fecal samples (real-time } \\
\text { qPCR and HPLC) } \\
\text { Serum samples (HPLC) }\end{array}$ & $\begin{array}{l}\text { - Firmicutes (e.g., Clostridium leptum and Faecalibacterium prausntizii) was } \\
\text { reduced and Escherichia coli was enriched in IBD. } \\
\text { - Microbial deconjugation, transformation and desulphation capability } \\
\text { were depleted in IBD. } \\
\text { - Fecal conjugated and 3-OH-sulfated BAs were increased, whilst serum } \\
\text { and fecal secondary BAs were reduced in IBD. }\end{array}$ \\
\hline $\begin{array}{l}\text { Sinha et al., } \\
2020 \text { [10] }\end{array}$ & $\begin{array}{l}17 \text { with UC and } \\
\text { seven with FAP }\end{array}$ & $\begin{array}{l}\text { Stool samples } \\
\text { (metagenomic sequencing } \\
\text { and metabolomic } \\
\text { analysis) }\end{array}$ & $\begin{array}{l}\text { - } \alpha \text {-Diversity was reduced and phylum Firmicutes and Ruminococcaceae } \\
\text { (in Clostridium cluster XIVa) were decreased in UC. } \\
\text { - Secondary BAs (LCA and DCA) were remarkably reduced and CDCA } \\
\text { was remarkably increased in UC. CA levels were also increased but not } \\
\text { significant in UC. }\end{array}$ \\
\hline $\begin{array}{l}\text { Franzosa et al., } \\
\quad 2019 \text { [15] }\end{array}$ & $\begin{array}{l}88 \text { with } C D, 76 \text { with } \\
\text { UC and } 56 \text { non-IBD }\end{array}$ & $\begin{array}{l}\text { Stool samples } \\
\text { (metagenomic sequencing } \\
\text { and metabolomic } \\
\text { analysis) }\end{array}$ & $\begin{array}{l}\text { - Roseburia hominis and Ruminococcus obeum were reduced in IBD. } \\
\text { Ruminococcus gnavus and Escherichia coli were increased in CD. } \\
\text { - Cholate and CDCA were increased in IBD, whilst secondary BAs (LCA } \\
\text { and DCA) were decreased in CD. }\end{array}$ \\
\hline $\begin{array}{l}\text { Jacobs et al., } \\
2016[16]\end{array}$ & $\begin{array}{l}26 \text { with } C D, 10 \text { with } \\
\text { UC and } 54 \text { healthy } \\
\text { first-degree } \\
\text { relatives }\end{array}$ & $\begin{array}{c}\text { Stool samples (16S rRNA } \\
\text { sequencing and HPLC) }\end{array}$ & $\begin{array}{l}\text { - Microbial diversity was reduced in CD. Bifidibacterium adolescentis and } \\
\text { Parabacteroides distasonis were enriched, whilst Faecalibacterium } \\
\text { prausntizii and Bacteroides fragilis were reduced in CD. } \\
\text { - CA, 7-keto-DCA, CDCA sulphate and 3-sulfo-DCA were increased } \\
\text { in CD. }\end{array}$ \\
\hline $\begin{array}{l}\text { Lloyd-Price et al., } \\
\quad 2019 \text { [18] }\end{array}$ & $\begin{array}{l}67 \text { with CD, } 38 \\
\text { with UC and } \\
27 \text { non-IBDs }\end{array}$ & $\begin{array}{l}\text { Stool samples } \\
\text { (metagenomic sequencing } \\
\text { and metabolomic } \\
\text { analysis) }\end{array}$ & $\begin{array}{l}\text { - } \alpha \text {-Diversity was decreased and Faecalibacterium prausnitzii and Roseburia } \\
\text { hominis were depleted, whilst Escherichia coli was enriched in CD. } \\
\text { - Primary BA cholate and conjugated BAs (CA, GCA, TCA and GCDCA) } \\
\text { were increased, whilst secondary BAs (LCA and DCA) were reduced } \\
\text { in IBD. }\end{array}$ \\
\hline $\begin{array}{l}\text { Wang et al., } \\
2021 \text { [19] }\end{array}$ & $\begin{array}{l}29 \text { pediatric } \\
\text { patients with } C D \\
\text { and } 20 \mathrm{HCs}\end{array}$ & $\begin{array}{c}\text { Fecal samples (16S rRNA } \\
\text { sequencing and } \\
\text { UPLC-MS) }\end{array}$ & $\begin{array}{l}\text { - No significant difference was found in } \alpha \text {-diversity between CD and HC. } \\
\text { The genera Bifidobacteria and Clostridium (clusters IV and XI) were } \\
\text { decreased in CD. } \\
\text { - CD showed an increased level of conjugated and primary BAs and } \\
\text { a decreased level of unconjugated and secondary BAs (DCA, LCA and } \\
\text { hyodeoxycholic acid). }\end{array}$ \\
\hline $\begin{array}{l}\text { Weng et al., } \\
2019 \text { [37] }\end{array}$ & $\begin{array}{c}173 \text { with } \mathrm{CD}, 107 \\
\text { with UC and } \\
42 \mathrm{HCs}\end{array}$ & $\begin{array}{l}\text { Fecal samples } \\
\text { (metagenomic sequencing } \\
\text { and metabolomic } \\
\text { analysis) } \\
\text { Mucosal biopsy samples } \\
\text { (16S rRNA sequencing) }\end{array}$ & $\begin{array}{l}\text { - } \alpha \text {-Diversity was remarkably reduced in CD. Enterococcus and } \\
\text { Hydrogenophilus were enriched in fecal and mucosal samples of IBD. } \\
\text { Proteobacteria was enriched in mucosal samples of IBD. } \\
\text { - } \quad \text { LCA, CDCA and tauro-LCA were remarkably decreased in IBD. }\end{array}$ \\
\hline $\begin{array}{l}\text { Murakami et al., } \\
2018 \text { [38] }\end{array}$ & $\begin{array}{l}\text { Six with } C D \text {, six } \\
\text { with UC and } \\
26 \mathrm{HCs}\end{array}$ & $\begin{array}{l}\text { Fecal samples (T-RFLP } \\
\text { analysis and HPLC) } \\
\text { Serum samples (HPLC) }\end{array}$ & $\begin{array}{l}\text { - The proportion of fecal Clostridium cluster XIVa was remarkably } \\
\text { reduced in IBD. } \\
\text { - Fecal and serum DCA/(DCA + CA) in IBD were reduced compared } \\
\text { with those in healthy subjects. }\end{array}$ \\
\hline $\begin{array}{l}\text { Diederen et al., } \\
2020 \text { [39] }\end{array}$ & $\begin{array}{l}43 \text { pediatric } \\
\text { patients with } \mathrm{CD} \\
\text { and } 18 \mathrm{HCs}\end{array}$ & $\begin{array}{c}\text { Fecal samples (16S rRNA } \\
\text { sequencing and HPLC) }\end{array}$ & $\begin{array}{l}\text { - OTU richness was reduced in CD but the diversity did not remarkably } \\
\text { differ between CD and HC. Eubacterium rectale, Bifidobacterium longum } \\
\text { and Ruminococcus bromii were increased, whilst Escherichia coli was } \\
\text { decreased in CD. } \\
\text { - The relative concentration of primary BAs was increased in CD. }\end{array}$ \\
\hline
\end{tabular}


Table 1. Cont.

\begin{tabular}{|c|c|c|c|}
\hline Publication & Patients & Samples and Methods & Major Findings \\
\hline $\begin{array}{l}\text { Yang et al., } \\
2021 \text { [22] }\end{array}$ & $\begin{array}{l}32 \text { patients with } \\
\mathrm{UC} \text { and } 23 \mathrm{HCs}\end{array}$ & $\begin{array}{c}\text { Fecal samples (16S rRNA } \\
\text { sequencing and } \\
\text { UPLC-MS) }\end{array}$ & $\begin{array}{l}\text { - Faecalibacterium, Roseburia, Butyricicoccus and Clostridium were reduced, } \\
\text { whilst Enterobacteriaceae, Enterobacteriales, and Escherichia_Shigella were } \\
\text { enriched in UC. } \\
\text { - The secondary BAs, such as LCA, DCA and tauro-LCA were decreased } \\
\text { significantly, whilst primary and conjugated BAs (CA, TCA and } \\
\text { G/TCDCA) were increased in UC. }\end{array}$ \\
\hline
\end{tabular}

Abbreviations: HPLC, high-performance liquid chromatography; T-RFLP, terminal restriction fragment length polymorphism analysis; UPLC-MS, ultraperformance liquid chromatography coupled with mass spectrometry; OTU, operational taxonomic unit; IBD, inflammatory bowel disease; UC, ulcerative colitis; CD, Crohn's disease; HC, healthy controls; FAP, familial adenomatous polyposis; BA, bile acid; CA, cholic acid; CDCA, chenodeoxycholic acid; DCA, deoxycholic acid; LCA, lithocholic acid; GCA, glycocholic acid; TCA, taurocholic acid; GCDCA, glycochenodeoxycholic acid.

Secondary bile acids, such as DCA and LCA, exhibited anti-inflammatory effect rather than sulphated bile acids. Duboc et al. investigated the effects of different bile acids on epithelial inflammatory response. Primary bile acids (CA and CDCA) showed no effect, whereas secondary bile acids (DCA and LCA) inhibited the IL-8 secretion after IL- $1 \beta$ stimulation in Caco-2 cells. Interestingly, sulphated LCA abolished the effect [9]. In addition, secondary bile acids exhibited anti-inflammatory effects in vivo. DCA and LCA alleviated inflammation in several murine colitis models, as featured by the improvement of weight loss, colon morphology and length, with decreased leukocyte infiltration, disease activity and fecal lipocalin 2 level [10]. Secondary bile acids and their derivatives (e.g., 3-oxoLCA and isoalloLCA) were demonstrated to promote Treg cell differentiation and inhibit Th17 cell differentiation $[6,42]$. Furthermore, bile acids played critical roles in intestinal innate immunity via bile acid-activated receptors [43]. Interestingly, a recent study found that high-dose and long-term intake of DCA may aggravate intestinal inflammation [44].

\subsection{Bile Acids Influence the Composition of Gut Microbiota}

The bile acids excreted into the intestine are further metabolized by gut microbiota and in turn, bile acids affect the microbial composition. As reported by Islam et al., administration of CA could bring about increased abundance in phylum Firmicutes, such as Clostridium cluster XIVa, and reduced abundance in phylum Bacteroidetes in rats [45]. Another study also found a significant increase in bile acid $7 \alpha$-dehydroxylating bacteria in mice supplemented with CA [46]. Bile acids have been demonstrated to exert direct and indirect effects on gut microbiota [47]. On the one hand, bile acids could directly inhibit the growth of bacteria by increasing cell membrane permeability and causing cell damage [48]. They could also induce DNA and oxidative damage in bacteria [47]. On the other hand, bile acids could influence bacteria indirectly through the FXR and VDR $[49,50]$. Specifically, FXR agonist GW4064 restrained the overgrowth of bacteria induced by biliary duct ligation in mice [50]. Cathelicidin is a major antimicrobial peptide that could curb bacterial growth. CDCA and UDCA induced the expression of cathelicidin through FXR and VDR in vitro. In vivo, UDCA therapy exhibited an ability to increase VDR and cathelicidin expression [49].

\subsection{Bile Acid-Activated Receptors}

Bile acids are natural ligands of several receptors and they are engaged in the regulation of metabolic and immune processes through activating the corresponding receptors [51,52]. Bile acid-activated receptors include FXR, TGR5, PXR and VDR. All of them are nuclear receptors except the membrane receptor TGR5 [43,51].

\subsubsection{FXR}

FXR is distributed predominately in intestinal epithelial cells, hepatocytes and some immune cells (e.g., macrophages and dendritic cells) in the gut and liver [43]. In enterocytes, the most potent ligand for FXR is CDCA, followed by DCA, LCA and CA [53]. Muricholic acids (MCAs) constitute a part of primary bile acids in mice, of which $\alpha$-MCA 
and $\beta$-MCA are potent FXR antagonists. The gut microbiota mainly affects FXR through change in bile acids. The antioxidant tempol could induce reduction in Lactobacillus and this change could lead to the impairment of BSH activity and subsequent accumulation of tauro- $\beta$-MCA and FXR inhibition [54]. Similarly, in patients with IBD, phylum Firmicutes, especially the C. leptum group endowed with BSH activity, was remarkably reduced [55]. FXR and microbiota have a bidirectional influence. The FXR agonist GW4064 restrains the bacterial overgrowth [50] and thus protects the intestinal tract from bacteria-induced damage. Zhang et al. have reported that the high-affinity FXR antagonist gly-MCA disturbs the gut community structure, as characterized by the reduced ratio of Firmicutes to Bacteroidetes, whilst the application of GW4064 reverses the alteration [56]. Besides, the synthetic FXR ligand 6-ethyl-CDCA (INT-747) could promote the production of cathelicidin [57]. Therefore, the activation and antagonism of FXR affect the intestinal bacteria.

Some studies showed that FXR is related to the occurrence of IBD. Downregulated expression of FXR mRNA in inflamed colonic mucosa was observed in patients with $\mathrm{CD}$ and colitis mice models [58]. Studies pointed that $F X R^{-/-}$mice exhibited increased expression of inflammatory cytokines and aggravated 2,4,6-trinitrobenzenesulfonic acid (TNBS) and dextran sulfate sodium (DSS)-induced colitis, whilst FXR activation could alleviate colitis via application of INT-747 [57,58]. FXR was involved in modulating intestinal immunity $[43,58]$ and it may influence IBD through immune activities. Immune perturbations, such as elevated infiltration of macrophages, were observed in $F X R^{-/-}$ mice. Macrophages isolated from TNBS-treated $F X R^{-I-}$ mice released more inflammatory cytokines than wild type (WT) mice. Conversely, FXR activation in macrophages inhibited the generation of nuclear factor- $\mathrm{kB}(\mathrm{NF}-\mathrm{kB})$-dependent pro-inflammatory cytokines, such as IL-6, IL-1 $\beta$ and tumor necrosis factor- $\alpha$ (TNF- $\alpha$ ) [58]. Another study found that the ligand INT-747 reduced TNF- $\alpha$ secretion in monocytes and dendritic cells [57]. The two studies identified that FXR activation alleviated colitis. Moreover, FXR could protect the intestinal barrier in vivo and vitro and decrease goblet cells loss, thus contributing to the inhibition of intestinal inflammation [57,59]. Gadaleta et al. investigated the role of downstream fibroblast growth factor 19 (FGF19) and found a reduced level of FGF19 in patients with CD [60]. In this study, FGF19-M52, a variant of the FGF19 protein was applied and demonstrated to maintain the intestinal barrier, inhibit inflammatory immune response (reduced macrophages recruitment and pro-inflammatory cytokines) and regulate the gut microbial community, leading to alleviation of colitis in a FXR-dependent manner. $\mathrm{Xu}$ et al. found that FXR agonist fexaramine could restore the FXR-FGF15 activity and normalize bile acid metabolism in mice. The abundance of SCFA-producing bacteria was elevated. As a result, FXR activation attenuated intestinal inflammation induced by highdose DCA. Besides, administration of antibiotics also reduced intestinal inflammation. This study hinted the key role of FXR and gut microbiota in intestinal inflammation [44]. Thus, the activation of FXR and its downstream signaling pathway exert protective effects on intestinal inflammation. The mechanism may involve restoration of bile acid metabolism and gut microbiota, as well as positive effects on intestinal immunity and barrier.

\subsubsection{TGR5}

TGR5 is another major and extensively studied bile acid-activated receptor [61]. Secondary bile acids, especially LCA and DCA, are the most potent ligands binding to TGR5 [53]. In addition, TGR5 participates in the modulation of metabolic process and immune response [51,61].

TGR5 could protect mice from colitis. TGR5 ${ }^{-/-}$mice presented higher susceptibility to colitis and more severe inflammation than WT mice. Activation of TGR 5 could ameliorate intestinal inflammation [62]. Sinha et al. demonstrated that the anti-inflammatory effects of LCA were closely related to TGR5 as the protective effect against colitis was lost in $T G R 5^{-/-}$mice compared with that in WT mice. They further studied the role of immune cells expressing TGR5 through bone marrow transplantation experiment. Based on the same DSS-induced colitis and LCA administration, the mice who received bone marrow 
from TGR5 ${ }^{-/-}$mice were in worse inflammatory condition than those who received it from WT mice. In addition, the former had more TNF- $\alpha^{+}$and $\mathrm{IL}-17^{+}$colonic leukocytes. The results implied that immune cells expressing TGR5 play an essential role in LCA protecting the host against colitis [10]. TGR5 may influence inflammation through regulating immune activities. Macrophages play significant roles in regulating cytokine production and inflammatory response in the gastrointestinal tract and they could be regulated by TGR5 [63]. Macrophages manifest the plasticity to differentiate into two distinct phenotypes: classically activated macrophages (M1) and alternatively activated macrophages (M2). M1 shows the pro-inflammatory property of producing cytokines IL-12, IL-6, IL-1 $\beta$ and TNF- $\alpha$, whilst M2 exhibits anti-inflammatory specialty characterized by the production of IL-10 [64,65]. Macrophage polarization under the regulation of TGR5 directly affects the tendency of inflammatory response (pro-inflammatory or anti-inflammatory) [7]. Several studies have found that TGR5 agonists (such as DCA, LCA and tauro-LCA) could suppress the production of TNF- $\alpha$ and IL-12 in lipopolysaccharide-treated macrophages. The IL-10/IL-12 ratio was also elevated, suggesting that macrophages transformed into the anti-inflammatory phenotype. TGR5 could induce cyclic adenosine monophosphate (cAMP) production and subsequent cAMP-dependent protein kinase $\mathrm{A}(\mathrm{PKA})$ activation, leading to the inhibition of NF- $\mathrm{kB}[66,67]$. Besides, TGR5 activation was proven to induce monocytes to differentiate into dendritic cells with reduced cytokine IL-12 via the TGR5-cAMP-PKA pathway [68]. Biagioli et al. reported that $T G R 5^{-1-}$ mice presented enhanced M1 recruitment and intestinal inflammation, whereas TGR5 agonist BAR501 promoted the macrophages shifting from M1 to M2 phenotype and brought about reduced pro-inflammatory cytokines and relieved experimental colitis. A recent study found that activation of the TGR5-cAMP-PKA axis also caused ubiquitination of Nod-like receptor protein 3 (NLRP3). As a result, the production of NLRP3 inflammasome and subsequent IL-1 $\beta$ excretion were blocked [69]. In addition to causing immune dysfunction, TGR5 deficiency contributed to the impaired gut mucosal barrier and increased intestinal permeability [62]. Therefore, the activation of TGR5 may relieve colitis by modulating immunity and improving the intestinal barrier function.

\subsubsection{PXR}

PXR is expressed in the liver and intestine and it could be activated by LCA and its metabolite 3-keto-LCA [51]. As the principal xenobiotic receptor, PXR could achieve detoxification and elimination of xenobiotics. Furthermore, PXR is involved in the regulation of inflammatory response, cell proliferation and migration [70]. PXR activation was proven to alter the structure of gut microbial community and regulate bile acids in a bacteria-dependent manner [71]. A recent study has pointed out that statin alters the diversity and composition of gut microbiota in a PXR-dependent manner [72]. Conversely, gut microbiota could modulate PXR through LCA production and another bacteria-derived metabolite indole 3-propionic acid, which is a tryptophan degradation product and a ligand for PXR [73].

In patients with UC, downregulated PXR and its target genes (mainly cellular detoxification and defense genes) were observed, hinting a possible link between PXR and the pathogenesis of IBD [74]. In addition, genetic variations of PXR were identified to be closely related to an increased risk of IBD $[75,76]$. Mice with PXR deficiency were more susceptible to colitis and showed more severe inflammation than the control, whereas the activation of PXR by agonists could protect from colitis [77]. Zhou et al. found that PXR activation inhibited NF- $\mathrm{kB}$ signaling, whereas deletion of PXR elevated the expression of NF- $\mathrm{kB}$ and NF- $\mathrm{kB}$ activation reciprocally suppressed the expression of PXR and its target genes [78]. The reciprocal suppression may account for a mechanistic link between PXR and inflammation signaling pathways. Studies showed that PXR may contribute to IBD protection via suppression of the NF- $\mathrm{kB}$ pathway. In mice treated with DSS, PXR activation suppressed NF-KB activity and inhibited the production of pro-inflammatory cytokines, leading to improvement of intestinal inflammation [77]. PXR gene ablation resulted in impaired intestinal barrier integrity and elevated expression of Toll-like receptor 4 (TLR4). 
Furthermore, TLR4 signaling was proven to be an essential causative pathway in intestinal barrier disruption because barrier defects were corrected in $P X R^{-/}-T L R 4^{-/}$mice. The PXR ligand indole 3-propionic acid could also decrease intestinal mucosal permeability and the expression of TNF- $\alpha$ via TLR4 signaling. This study suggested that PXR exerts an anti-inflammatory effect by negatively modulating TLR4 signaling [73].

\subsubsection{VDR}

VDR is widely expressed in various tissues, activated by 1,25-dihydroxyvitamin D and involved in metabolic and immunologic process modulation. Besides, VDR is activated by LCA and 3-oxo-LCA. It helps detoxify LCA in the liver and intestine by inducing the expression of cytochrome P450 enzyme [79]. Gut microbiota could modulate VDR by altering bile acid metabolism because bile acids serve as ligands and regulators of VDR expression $[49,79]$. Inversely, the human genetic variations of VDR were identified to affect the microbial diversity and metabolism. The microbiota in $V D R^{-/-}$mice extensively changed compared with that in WT mice [80].

VDR was identified as a susceptibility gene for IBD [81]. Disturbance of VDR expression and signal were reported in patients with IBD [82]. VDR expression in the colon was inversely correlated with the histological score in IBD and VDR staining showed a lower level in the diseased section than the quiescent segment [83]. This study may indicate the protective effect of VDR on intestinal inflammation. On the basis of the results of VDR expression change in IBD, the intestinal inflammation and corresponding pathological mechanism were further studied in VDR-deficient mice. Research showed that $V D R^{-/-}$ mice developed more severe colitis after TNBS treatment, along with increased intestinal epithelial cell apoptosis and mucosal barrier permeability. The resulting bacterial invasion could lead to immune system disorder, as characterized by the unbalanced Th1/Th17 response. Immune dysregulation and inflammation could be corrected by the depletion of bacteria with antibiotics, suggesting that VDR worked in a bacteria-dependent manner [84]. In a study carried out by Liu et al., epithelial VDR signaling inhibited epithelium apoptosis by suppressing NF- $\mathrm{BB}$ signal and the key mediator of apoptosis, the p53-up-regulated modulator of apoptosis. As a result, overexpression of VDR in mice could maintain epithelial barrier function and attenuate colitis [82]. A recently published study showed an indispensable role of VDR in maintaining colonic Treg cell homeostasis, which was critical to resistance to DSS-induced colitis [6]. Besides, Paneth cells could sense gut bacteria through MyD88-dependent TLR activation, inducing the production of antimicrobial peptides [85]. The absence of VDR downregulated autophagy-related 16-like 1 and Beclin-1 resulted in deficits in autophagy [86] and impairment of Paneth cell function [87]. Abnormal Paneth cells and reduced lysozyme may account for gut dysbiosis in mutant mice, a crucial factor in intestinal inflammation [87]. Therefore, VDR may act as a modulator of colitis by regulating autophagy and Paneth cells and further altering the gut community. Meanwhile, administration of microbiota-derived butyrate elevated the expression of VDR and relieved inflammation in DSS-treated mice, thus showing the bidirectional effects between gut microbiota and VDR in intestinal inflammation.

\section{Therapeutic Target of Bile Acid-Gut Microbiota Axis for IBD}

On the basis of the changes and effects of gut microbiota and bile acids in IBD, several therapies that target the bile acid-gut microbiota axis were summarized. The relevant studies are listed in Table 2.

Table 2. Therapy targeting bile acid-gut microbiota axis for inflammatory bowel disease.

\begin{tabular}{ccccc}
\hline Publication & Subjects & Treatment & Samples and Methods & Major Findings \\
\hline $\begin{array}{c}\text { Diederen et al., } \\
2020 \text { [39] }\end{array}$ & $\begin{array}{c}\text { patients with CD } \\
\text { and 18 healthy } \\
\text { controls }\end{array}$ & $\begin{array}{c}\text { EEN for 6 weeks } \\
\text { followed by 2 weeks } \\
\text { of EEN tapering }\end{array}$ & $\begin{array}{c}\text { Fecal samples (16S rRNA } \\
\text { sequencing and HPLC) }\end{array}$ & $\begin{array}{l}\text { EEN decreased the microbiota diversity and } \\
\text { reduced trimethylamine and cadaverine } \\
\text { towards control levels. } \\
\text { Reduced microbial metabolism of BAs in CD } \\
\text { was partially normalized during EEN. }\end{array}$ \\
\hline
\end{tabular}


Table 2. Cont.

\begin{tabular}{|c|c|c|c|c|}
\hline Publication & Subjects & Treatment & Samples and Methods & Major Findings \\
\hline $\begin{array}{l}\text { Paramsothy et al., } \\
2019 \text { [88] }\end{array}$ & $\begin{array}{l}81 \text { patients with } \\
\text { active UC }\end{array}$ & $\begin{array}{l}\text { FMT or placebo } \\
\text { colonoscopic infusion, } \\
\text { followed by enemas } \\
5 \text { days per week for } \\
8 \text { weeks }\end{array}$ & $\begin{array}{l}\text { Fecal samples } \\
\text { (metagenomic and } \\
\text { metabolomic analysis) } \\
\text { Colonic biopsy samples } \\
\text { (16S rRNA gene and } \\
\text { transcript sequencing) }\end{array}$ & $\begin{array}{l}\text { - Microbial diversity was increased and the } \\
\text { composition was altered after FMT. The } \\
\text { patients in remission had enriched } \\
\text { Eubacterium hallii and Roseburia inulivorans. } \\
\text { - Mucosal microbiota showed increased } \\
\text { - } \text {-diversity after FMT. } \\
\text { Patients in remission had increased levels of } \\
\text { secondary BA (dehydrolithocholate). }\end{array}$ \\
\hline $\begin{array}{l}\text { Wang et al., } \\
2021 \text { [19] }\end{array}$ & 29 pediatric $\mathrm{CDs}$ & $\begin{array}{l}\text { Infliximab infusion for } \\
\text { 3-6 times }\end{array}$ & $\begin{array}{c}\text { Fecal samples (16S rRNA } \\
\text { sequencing and } \\
\text { UPLC-MS) }\end{array}$ & $\begin{array}{l}\text { - The abundances of Blautia, Clostridium IV, } \\
\text { Collinsella, Eubacterium and Ruminococcus were } \\
\text { increased after treatment. } \\
\text { - The ratios of unconjugated/conjugated BAs } \\
\text { and secondary/primary BAs were elevated. }\end{array}$ \\
\hline $\begin{array}{l}\text { Wang et al., } \\
2019 \text { [89] }\end{array}$ & $\begin{array}{l}\text { Canine model of } \\
\text { chronic } \\
\text { inflammatory } \\
\text { enteropathy }\end{array}$ & $\begin{array}{l}\text { Hydrolyzed protein } \\
\text { diet for } 6 \text { weeks }\end{array}$ & $\begin{array}{c}\text { Fecal samples } \\
\text { (metagenomic and } \\
\text { metabolomic analysis) }\end{array}$ & $\begin{array}{l}\text { - Gut microbiota was restored, as marked by } \\
\text { reduced pathogens and increased Clostridium } \\
\text { hiranonis after treatment. } \\
\text { - The levels of secondary BAs (LCA and DCA) } \\
\text { were increased after treatment. }\end{array}$ \\
\hline $\begin{array}{l}\text { Ke et al., } \\
2020[90]\end{array}$ & $\begin{array}{l}\text { Mice with } \\
\text { DSS-induced } \\
\text { chronic colitis }\end{array}$ & $\begin{array}{l}\text { Fucose gavage for } \\
57 \text { days }\end{array}$ & $\begin{array}{l}\text { Ileal tissue lysates and } \\
\text { colonic feces (16S rRNA } \\
\text { sequencing and } \\
\text { UPLC-MS) }\end{array}$ & $\begin{array}{l}\text { - Fucose increased } \alpha \text {-diversity and reversed the } \\
\text { decreased ratio of Firmicutes to Bacteroidetes. } \\
\text { The level of tauro- } \beta \text {-MCA and TCA was } \\
\text { decreased and the abnormal ratio of } \\
\text { conjugated/unconjugated BAs was restored } \\
\text { after treatment. }\end{array}$ \\
\hline $\begin{array}{l}\text { Jia et al., } \\
2020[91]\end{array}$ & $\begin{array}{l}\text { Mice with } \\
\text { DSS-induced } \\
\text { acute colitis }\end{array}$ & $\begin{array}{l}\text { Oral total alkaloids of } \\
\text { Sophora } \\
\text { alopecuroides L. for } \\
7 \text { days }\end{array}$ & $\begin{array}{l}\text { Cecum content (16S rDNA } \\
\text { gene sequencing) } \\
\text { Liver, bile, serum, cecum } \\
\text { content and colon samples } \\
\text { (UPLC-MS) }\end{array}$ & $\begin{array}{l}\text { - The abundance of Firmicutes was increased, } \\
\text { whereas that of Bacteroidetes was decreased } \\
\text { after treatment. } \\
\text { - The elevated MCAs and CA were restored } \\
\text { after treatment. }\end{array}$ \\
\hline $\begin{array}{l}\text { Bossche et al., } \\
2017 \text { [12] }\end{array}$ & $\begin{array}{l}\text { Mice with } \\
\text { DSS-induced } \\
\text { acute colitis }\end{array}$ & $\begin{array}{l}\text { Daily gavage of } \\
\text { UDCA, TUDCA, } \\
\text { GUDCA or placebo } \\
\text { for } 10 \text { days }\end{array}$ & $\begin{array}{c}\text { Fecal samples (16S rRNA } \\
\text { sequencing and HPLC) }\end{array}$ & $\begin{array}{l}\text { - The ratio of Firmicutes/Bacteroidetes was } \\
\text { normalized and the abundance of Clostridium } \\
\text { cluster XIVa and Akkermansia muciniphila was } \\
\text { increased. } \\
\text { - The concentrations of UDCA, TUDCA and } \\
\text { LCA were remarkably elevated after } \\
\text { treatments. }\end{array}$ \\
\hline
\end{tabular}

Abbreviations: FMT, fecal microbiota transplantation; EEN, exclusive enteral nutrition; IBD, inflammatory bowel disease; UC, ulcerative colitis; CD, Crohn's disease; DSS, dextran sulfate sodium; BA, bile acid; HPLC, high-performance liquid chromatography; UPLC-MS, ultraperformance liquid chromatography coupled with mass spectrometry; MCA, muricholic acids; CA, cholic acid; TCA, taurocholic acid; UDCA, ursodeoxycholic acid; TUDCA, tauroursodeoxycholic acid; GUDCA, glycoursodeoxycholic acid; DCA, deoxycholic acid; LCA, lithocholic acid.

\subsection{Dietary Therapy}

Epidemiologic data have shown the association between diets and risk of IBD [92]. Diet could rapidly and remarkably alter the human gut microbiome and bile acid pool $[93,94]$. Specific diet-induced alteration of bile acids and microbiota could activate immune cells [32] and increase intestinal permeability [95], leading to the occurrence of intestinal inflammation in mice. Thus, improving IBD by adjusting diets, resulting in the modification of the bile acid-gut microbiota axis, is reasonable. Wang et al. found that a hydrolyzed protein diet could induce relief of chronic inflammation in a canine model. The relief was linked with the increased levels of LCA and DCA and restored gut microbiota marked by reduced pathogens and increased bile acid-producing Clostridium hiranonis [89]. Other dietary substances, such as fucose and total alkaloids of Sophora alopecuroides L., also presented some therapeutic effects on colitis in mice $[90,91]$. They could restore the gut dysbiosis and increase the ratio of Firmicutes / Bacteroidetes. Besides, the levels of primary and conjugated bile acids declined after treatment and they were similar to those of the control group. Exclusive enteral nutrition (EEN) is a widely studied and established dietary therapy mainly applied to induce remission of pediatric CD [96,97]. EEN may exert antiinflammatory effects through modulating microbiota, bile acid metabolism and immune 
activities $[98,99]$. Studies have found that EEN exhibited effects on the composition and function of microbiota during the treatment of pediatric CD [100,101]. Furthermore, EEN partially restored the abnormal composition of bile acids in patients with $\mathrm{CD}$ and brought about increased LCA with reduced primary and conjugated bile acids [39]. Intriguingly, patients with different bile acid profiles and microbial communities have distinct responses to EEN. Patients with primary bile acid as the dominant bile acid showed non-sustained remission or relapse after EEN therapy. They exhibited decreased gut microbial diversity, accompanied by decreased abundance of Ruminococcaceae and Lachnospiraceae, and increased abundance of phylum Proteobacteria [102]. By contrast, studies in adults have exhibited variable results, possibly due to poor adherence to the treatment [103]. Overall, dietary therapy is likely to be a relatively safe approach. However, studies assessing the effects of diverse diets in IBD are difficult owing to various confounding factors and the compelling evidence at present are insufficient. More randomized controlled trials (RCTs) determining the efficacy and further mechanism of specific diet in pediatric and adult populations are warranted. Besides, in view of the challenges of long-term adherence to most existing diet therapies, more accessible nutritional schemes should be explored.

\subsection{Probiotics and Prebiotics}

Probiotic therapy is a method of introducing specific bacteria with well-recognized benefits to competitively inhibit pathogens and normalize the composition of gut microbiota [104]. The most widely used probiotics are Bifidobacterium and Lactobacillus genera, as well as Lactococcus spp., E. coli Nissle 1917 and Streptococcus thermophilus [105]. Probiotics have been shown to be effective in improving IBD in several clinical studies. E. coli Nissle 1917 is a well-studied strain that exhibits a comparable efficacy and safety of maintaining remission for UC with mesalazine [106-108]. Other species of probiotics such as Bifidobacterium and Lactobacillus were also effective in patients with UC [109-111]. Compared with the placebo group, probiotics brought about more significant endoscopic and histopathological improvement and lower clinical activity index [109,111]. Probiotics were also more effective for prolonging clinical remission in patients with UC [110]. VSL\#3 is a mixture of 8 strains of probiotics, consisting of 4 Lactobacillus strains, 3 Bifidobacterium strains and 1 Streptococcus strain. It has been shown that VSL\#3 is effective in inducing and maintaining remission in patients with UC [112,113]. As an adjunct to standard therapy, VSL\#3 presented better efficacy than single standard therapy both in adults [112] and children [113] with UC. The disease activity index was significantly lower in VSL\#3 group compared to the placebo group. In patients with UC in the presence of 5-aminosalicylic acid intolerance, the use of VSL\#3 was even more important [114]. Probiotics such as VSL\#3 and E. coli Nissle 1917 have been recommended by European Society for Clinical Nutrition and Metabolism for the treatment of mild or moderate UC [96]. Probiotics tend to restore the abundance of protective bacteria, enhance the intestinal epithelial barrier function and regulate immune activity in the host, which may account for the amelioration of gut inflammation $[115,116]$. Furthermore, probiotics (Lactobacillus plantarum CCFM8661, Lactobacillus reuteri NCIMB 30242 and VSL\#3) have been demonstrated to influence bile acid metabolism via FGF19/FGF15 in humans/mice, such as promoting the synthesis and excretion of bile acids [117-119]. VSL\#3 increased the abundance of Bifidobacteriaceae and Lactobacillaceae with elevated BSH activity, leading to decreased conjugated/unconjugated BAs [119]. However, probiotics usually exhibit low or no effect on CD [120-122].

Based on probiotics, researchers have made further efforts. Unlike traditional single probiotics or simple combination, a recent study has proposed the designed bacterial consortia [123]. The bacterial consortia were designed to interdependently restore the microbial composition and function in patients with IBD. The goal was to provide and replenish key therapeutic functions (e.g., conversion of secondary bile acids, especially DCA and LCA, synthesis of SCFAs and indole, synthesis of antimicrobials). The bacterial consortia were networks of metabolically interdependent strains, consisted of more than 10 human strains, referred to as GUT-103 or GUT-108. They were demonstrated to prevent 
and treat experimental colitis in mice. They reversed gut dysbiosis and restored functionality. Specifically, they could perform varieties of functions, including but not limited to $7-\alpha$-dehydroxylation. Although this attempt is still in the preliminary stage, it is indeed a direction worth further study.

Prebiotics, defined as 'substrates that are selectively utilized by host microorganisms conferring a health benefit', could promote the growth and metabolic activity of the beneficial resident bacteria of the host. The most commonly available prebiotics are lactulose, fructo-oligosaccharide, galacto-oligosaccharide and inulin [124]. Previous clinical practice has revealed the beneficial effect of prebiotics (e.g., inulin and oligofructose) in UC treatment $[125,126]$. Prebiotics are usually used in combination with probiotics, named synbiotics. In addition to improving the growth of probiotics, such as Bifidobacterium, Lachnospiraceae and Ruminococcaceae [127,128], prebiotics could affect the production of microbial metabolites SCFAs and bile acids [126,129]. For example, inulin increased the concentration of fecal DCA and LCA in dogs [129]. Overall, probiotics and prebiotics may regulate gut homeostasis by altering the profiles of bacteria and bile acids and be involved in the remission of intestinal inflammation. However, more studies are needed to determine the clear benefits and underlying mechanism.

\subsection{Engineered Bacteria}

Researchers have recently engineered microbes through synthetic biology tools to achieve targeted treatment. The engineered bacteria have been studied under several disease conditions, such as colitis, cancer and pathogenic infection. However, overall, the therapeutic application of engineered bacteria is still in the preliminary research stage, mainly in animal subjects. The following are several application examples of engineered bacteria in the treatment of colitis. Engineered Lactococcus lactis was designed to secrete IL-10 [130] or IL-27 [131] and attenuate colitis. This strain could increase the production of IL-10 and inhibit the production of pro-inflammatory cytokines, such as IL-6, IFN- $\gamma$ and IL-23. Engineered E. coli Nissle 1917 produced trefoil factors (TFFs) that promoted gut barrier function and protected mice from colitis through barrier protection and immune regulation [132]. Similarly, TFF was expressed in engineered Lactococcus lactis and presented a protective effect [133]. Therefore, engineered bacteria could be a candidate therapy though the mechanisms of action are not yet fully understood. Campbell et al. have developed an engineered Bacteroides strain that produced iso-DCA and further increased colonic Treg cells. Iso-DCA interacted with FXR in dendritic cells to enhance its Treg induction [134]. This study demonstrated that engineered bacteria also have crosstalk with bile acids and are engaged in immune regulation, which may play a role in the relief of colitis.

\subsection{Fecal Microbiota Transplantation (FMT)}

FMT is a manipulation of introducing microorganisms from pre-screened healthy donors into patients to ameliorate gut dysbiosis of recipients by normalizing diversity and the function of microbiota [135]. Over the past few decades, FMT has been successfully used to treat Clostridioides difficile infections. The mechanisms involve competition of symbiotic microbiota, restoration of bile acid metabolism and improvement of intestinal barrier via mucosal immunity [136]. Unlike probiotics, FMT brings about long-term engraftment [137]. Furthermore, FMT equipped with a largely distinct scale and content from probiotics due to approximately $10^{11}$ bacterial cells per gram of wet stool, along with fungi, viruses and archaea [138] is expected to establish a broadened microorganic equilibrium beyond bacteria [139]. Several well-designed RCTs have investigated FMT in patients with mild to moderate UC, with the endpoint of steroid-free clinical remission and endoscopic improvement. FMT presented therapeutic benefits over placebo [140-142], suggesting that it is a promising induction therapy for UC remission. Paramsothy et al. have found that the improved microbial community with enrichment of Roseburia inulivorans and Eubacterium hallii and the increased levels of SCFAs and secondary bile acid (dehydrolithocholate) after FMT were responsible for the induction of remission [88]. By contrast, RCTs in CD are 
limited. Sokol et al. recently performed the first RCT to evaluate FMT in patients with CD. In this study, patients treated with FMT showed significant improvement in endoscopic result and C-reactive protein level compared with the control. The clinical remission rate was higher with FMT, whereas no significant difference was found in the control, which may be attributed to insufficient subjects [143]. An earlier uncontrolled cohort study also reported effective clinical remission but lacked the evaluation of endoscopic remission [144]. These trials revealed that FMT is a potential approach to CD remission. However, RCTs involving a large scale of participants should be carried out to explore the effects of FMT on patients with $\mathrm{CD}$.

Taken together, FMT is a promising therapy for IBD remission. However, the current studies presented variable and inconsistent results in the efficacy of remission, possibly because of the different experimental designs, such as donor selection, application timing and dosage, delivery approaches and efficacy evaluation [145]. Most importantly, safety problem is not negligible due to a reported death incident induced by antibiotic-resistant bacterial infection after FMT [146]. Thus, establishing safe and stable therapeutic protocols should be the priority in clinical practice.

\subsection{UDCA}

UDCA is a secondary bile acid derived from CDCA and it presents at a low concentration in humans [147]. It has well-established therapeutic properties and it is originally used to treat cholestatic liver diseases [148]. UDCA could also improve colitogenic dysbiosis. In particular, the ratio of Firmicutes/Bacteroidetes was normalized and the abundance of Clostridium cluster XIVa and Akkermansia muciniphila was increased. As a result, colitis was relieved in mice [12]. UDCA could upregulate the expression of FXR and VDR and restore bile acid homeostasis [149]. Furthermore, UDCA could reduce the production of pro-inflammatory cytokines [150], inhibit enterocyte death and protect intestinal epithelial barrier integrity [151]. The above effects are remarkably associated with the suppression of intestinal inflammation. However, the clinical practice of UDCA therapy in IBD remission is rare thus far.

Patients with IBD have a high risk of developing colorectal dysplasia and cancer [2]. Clinical trials have shown that UDCA could reduce the risks in patients with UC [152]. The abundances of F. prausnitzii and Ruminococcus gnavus were increased and decreased, respectively, by UDCA treatment and this finding is associated with the lower risk of colorectal adenoma in men than in women [153]. However, a study has suggested that long-term administration of high-dose UDCA may increase the risk [154]. Therefore, the clinical use of UDCA for patients with IBD, especially in terms of dosage and duration, still needs to be prudent.

Primary sclerosing cholangitis (PSC) is usually linked with IBD, especially UC [155]. Up to $66 \%$ of patients with PSC have coexistent IBD (UC accounts for $75 \%$ ). Patients with PSC-IBD have remarkably different microbiota profiles and impaired bile acid metabolism compared with healthy controls. The bile-acid signaling pathways are also upregulated [156]. UDCA improves serum liver biochemistry and histology index but shows no long-term benefit. Thus, it remains controversial in the treatment of PSC [157].

\section{Conclusions}

Accumulating evidence has recently shown the link between bile acids and gut microbiota and their roles in IBD have caught much attention. However, the intricate interactions between the two in IBD need further elaboration. Gut microbiota is implicated in bile acid metabolism and it affects the composition of bile acids. Inversely, the altered bile acid pool could further disturb microbial homeostasis. Thus, gut dysbiosis, abnormal bile acid profile, and bile acid-activated receptors synergically contribute to IBD development. In this study, several therapies for IBD targeting the bile acid-gut microbiota axis were summarized. In the future, the recovery of bacterial function may be an important direction of treatment of IBD, including further research on probiotics, standardization of FMT, individualized 
microbial therapy, development of engineered bacteria and bacterial consortia and so on. These therapies appeared to be promising candidate treatments but the clinical efficacy and mechanisms still need to be confirmed by further studies.

Author Contributions: M.Y., Y.G. and H.C. contributed conception and prepared the manuscript. L.L. and T.L. searched the literature and wrote sections of the manuscript. X.S. and Y.S. prepared the figure. M.Y., Y.G. and L.L. revised the manuscript. X.C., B.W., K.J. and H.C. organized the framework. All authors have read and agreed to the published version of the manuscript.

Funding: This work was funded by the National Natural Science Foundation of China, grant number 82070545 and 81970477; Key Project of Science and Technology Pillar Program of Tianjin, grant number 20YFZCSY00020.

Acknowledgments: Figures have been modified from Servier Medical Art (http:/ /smart.servier.com/ (accessed on 15 June 2021)), licensed under a Creative Common Attribution 3.0 Generic License. (https://creativecommons.org/licenses/by/3.0/).

Conflicts of Interest: The authors declare no conflict of interest.

\section{References}

1. Ng, S.C.; Shi, H.Y.; Hamidi, N.; Underwood, F.E.; Tang, W.; Benchimol, E.I.; Panaccione, R.; Ghosh, S.; Wu, J.C.Y.; Chan, F.K.L.; et al. Worldwide incidence and prevalence of inflammatory bowel disease in the 21st century: A systematic review of population-based studies. Lancet 2018, 390, 2769-2778. [CrossRef]

2. Nadeem, M.S.; Kumar, V.; Al-Abbasi, F.A.; Kamal, M.A.; Anwar, F. Risk of colorectal cancer in inflammatory bowel diseases. Semin. Cancer Biol. 2020, 64, 51-60. [CrossRef]

3. Shouval, D.S.; Rufo, P.A. The Role of Environmental Factors in the Pathogenesis of Inflammatory Bowel Diseases: A Review. JAMA Pediatr. 2017, 171, 999-1005. [CrossRef]

4. Kaplan, G.G.; Ng, S.C. Understanding and Preventing the Global Increase of Inflammatory Bowel Disease. Gastroenterology 2017, 152, 313-321. [CrossRef]

5. Weingarden, A.R.; Vaughn, B.P. Intestinal microbiota, fecal microbiota transplantation, and inflammatory bowel disease. Gut Microbes 2017, 8, 238-252. [CrossRef] [PubMed]

6. Song, X.; Sun, X.; Oh, S.F.; Wu, M.; Zhang, Y.; Zheng, W.; Geva-Zatorsky, N.; Jupp, R.; Mathis, D.; Benoist, C.; et al. Microbial bile acid metabolites modulate gut ROR $\gamma$ regulatory T cell homeostasis. Nature 2020, 577, 410-415. [CrossRef] [PubMed]

7. Jia, W.; Xie, G.; Jia, W. Bile acid-microbiota crosstalk in gastrointestinal inflammation and carcinogenesis. Nat. Rev. Gastroenterol. Hepatol. 2018, 15, 111-128. [CrossRef] [PubMed]

8. Gérard, P. Metabolism of cholesterol and bile acids by the gut microbiota. Pathogens 2013, 3, 14-24. [CrossRef]

9. Duboc, H.; Rajca, S.; Rainteau, D.; Benarous, D.; Maubert, M.A.; Quervain, E.; Thomas, G.; Barbu, V.; Humbert, L.; Despras, G.; et al. Connecting dysbiosis, bile-acid dysmetabolism and gut inflammation in inflammatory bowel diseases. Gut 2013, 62, 531-539. [CrossRef] [PubMed]

10. Sinha, S.R.; Haileselassie, Y.; Nguyen, L.P.; Tropini, C.; Wang, M.; Becker, L.S.; Sim, D.; Jarr, K.; Spear, E.T.; Singh, G.; et al. DysbiosisInduced Secondary Bile Acid Deficiency Promotes Intestinal Inflammation. Cell Host Microbe 2020, 27, 659-670. [CrossRef]

11. Wohlgemuth, S.; Keller, S.; Kertscher, R.; Stadion, M.; Haller, D.; Kisling, S.; Jahreis, G.; Blaut, M.; Loh, G. Intestinal steroid profiles and microbiota composition in colitic mice. Gut Microbes 2011, 2, 159-166. [CrossRef] [PubMed]

12. Van den Bossche, L.; Hindryckx, P.; Devisscher, L.; Devriese, S.; Van Welden, S.; Holvoet, T.; Vilchez-Vargas, R.; Vital, M.; Pieper, D.H.; Vanden Bussche, J.; et al. Ursodeoxycholic Acid and Its Taurine- or Glycine-Conjugated Species Reduce Colitogenic Dysbiosis and Equally Suppress Experimental Colitis in Mice. Appl. Environ. Microbiol. 2017, 83, e02766-16. [CrossRef] [PubMed]

13. Glassner, K.L.; Abraham, B.P.; Quigley, E.M.M. The microbiome and inflammatory bowel disease. J. Allergy Clin. Immunol. 2020, 145, 16-27. [CrossRef]

14. Pascal, V.; Pozuelo, M.; Borruel, N.; Casellas, F.; Campos, D.; Santiago, A.; Martinez, X.; Varela, E.; Sarrabayrouse, G.; Machiels, K.; et al. A microbial signature for Crohn's disease. Gut 2017, 66, 813-822. [CrossRef]

15. Franzosa, E.A.; Sirota-Madi, A.; Avila-Pacheco, J.; Fornelos, N.; Haiser, H.J.; Reinker, S.; Vatanen, T.; Hall, A.B.; Mallick, H.; McIver, L.J.; et al. Gut microbiome structure and metabolic activity in inflammatory bowel disease. Nat. Microbiol. 2019, 4, 293-305. [CrossRef] [PubMed]

16. Jacobs, J.P.; Goudarzi, M.; Singh, N.; Tong, M.; McHardy, I.H.; Ruegger, P.; Asadourian, M.; Moon, B.-H.; Ayson, A.; Borneman, J.; et al. A Disease-Associated Microbial and Metabolomics State in Relatives of Pediatric Inflammatory Bowel Disease Patients. Cell. Mol. Gastroenterol. Hepatol. 2016, 2, 750-766. [CrossRef] [PubMed] 
17. Gevers, D.; Kugathasan, S.; Denson, L.A.; Vázquez-Baeza, Y.; Van Treuren, W.; Ren, B.; Schwager, E.; Knights, D.; Song, S.J.; Yassour, M.; et al. The treatment-naive microbiome in new-onset Crohn's disease. Cell Host Microbe 2014, 15, 382-392. [CrossRef]

18. Lloyd-Price, J.; Arze, C.; Ananthakrishnan, A.N.; Schirmer, M.; Avila-Pacheco, J.; Poon, T.W.; Andrews, E.; Ajami, N.J.; Bonham, K.S.; Brislawn, C.J.; et al. Multi-omics of the gut microbial ecosystem in inflammatory bowel diseases. Nature 2019, 569, 655-662. [CrossRef]

19. Wang, Y.; Gao, X.; Zhang, X.; Xiao, F.; Hu, H.; Li, X.; Dong, F.; Sun, M.; Xiao, Y.; Ge, T.; et al. Microbial and metabolic features associated with outcome of infliximab therapy in pediatric Crohn's disease. Gut Microbes 2021, 13. [CrossRef]

20. Machiels, K.; Joossens, M.; Sabino, J.; De Preter, V.; Arijs, I.; Eeckhaut, V.; Ballet, V.; Claes, K.; Van Immerseel, F.; Verbeke, K.; et al. A decrease of the butyrate-producing species Roseburia hominis and Faecalibacterium prausnitzii defines dysbiosis in patients with ulcerative colitis. Gut 2014, 63, 1275-1283. [CrossRef]

21. Knoll, R.L.; Forslund, K.; Kultima, J.R.; Meyer, C.U.; Kullmer, U.; Sunagawa, S.; Bork, P.; Gehring, S. Gut microbiota differs between children with Inflammatory Bowel Disease and healthy siblings in taxonomic and functional composition: A metagenomic analysis. Am. J. Physiol. Gastrointest. Liver Physiol. 2017, 312, G327-G339. [CrossRef]

22. Yang, Z.-H.; Liu, F.; Zhu, X.-R.; Suo, F.-Y.; Jia, Z.-J.; Yao, S.-K. Altered profiles of fecal bile acids correlate with gut microbiota and inflammatory responses in patients with ulcerative colitis. World J. Gastroenterol. 2021, 27, 3609-3629. [CrossRef]

23. Ansari, I.; Raddatz, G.; Gutekunst, J.; Ridnik, M.; Cohen, D.; Abu-Remaileh, M.; Tuganbaev, T.; Shapiro, H.; Pikarsky, E.; Elinav, E.; et al. The microbiota programs DNA methylation to control intestinal homeostasis and inflammation. Nat. Microbiol. 2020, 5, 610-619. [CrossRef]

24. Kelly, C.J.; Zheng, L.; Campbell, E.L.; Saeedi, B.; Scholz, C.C.; Bayless, A.J.; Wilson, K.E.; Glover, L.E.; Kominsky, D.J.; Magnuson, A.; et al. Crosstalk between Microbiota-Derived Short-Chain Fatty Acids and Intestinal Epithelial HIF Augments Tissue Barrier Function. Cell Host Microbe 2015, 17, 662-671. [CrossRef] [PubMed]

25. Furusawa, Y.; Obata, Y.; Fukuda, S.; Endo, T.A.; Nakato, G.; Takahashi, D.; Nakanishi, Y.; Uetake, C.; Kato, K.; Kato, T.; et al. Commensal microbe-derived butyrate induces the differentiation of colonic regulatory T cells. Nature 2013, 504, 446-450. [CrossRef] [PubMed]

26. Gury-BenAri, M.; Thaiss, C.A.; Serafini, N.; Winter, D.R.; Giladi, A.; Lara-Astiaso, D.; Levy, M.; Salame, T.M.; Weiner, A.; David, E.; et al. The Spectrum and Regulatory Landscape of Intestinal Innate Lymphoid Cells Are Shaped by the Microbiome. Cell 2016, 166, 1231-1246. [CrossRef] [PubMed]

27. Castellanos, J.G.; Longman, R.S. Innate lymphoid cells link gut microbes with mucosal T cell immunity. Gut Microbes 2020, 11, 231-236. [CrossRef]

28. Bernink, J.H.; Krabbendam, L.; Germar, K.; de Jong, E.; Gronke, K.; Kofoed-Nielsen, M.; Munneke, J.M.; Hazenberg, M.D.; Villaudy, J.; Buskens, C.J.; et al. Interleukin-12 and -23 Control Plasticity of CD127(+) Group 1 and Group 3 Innate Lymphoid Cells in the Intestinal Lamina Propria. Immunity 2015, 43, 146-160. [CrossRef]

29. Zeng, B.; Shi, S.; Ashworth, G.; Dong, C.; Liu, J.; Xing, F. ILC3 function as a double-edged sword in inflammatory bowel diseases. Cell Death Dis. 2019, 10, 315. [CrossRef]

30. Britton, G.J.; Contijoch, E.J.; Mogno, I.; Vennaro, O.H.; Llewellyn, S.R.; Ng, R.; Li, Z.; Mortha, A.; Merad, M.; Das, A.; et al. Microbiotas from Humans with Inflammatory Bowel Disease Alter the Balance of Gut Th17 and ROR $\gamma \mathrm{t}$ Regulatory T Cells and Exacerbate Colitis in Mice. Immunity 2019, 50, 212-224. [CrossRef]

31. Neurath, M.F. Targeting immune cell circuits and trafficking in inflammatory bowel disease. Nat. Immunol. 2019, 20, 970-979. [CrossRef] [PubMed]

32. Devkota, S.; Wang, Y.; Musch, M.W.; Leone, V.; Fehlner-Peach, H.; Nadimpalli, A.; Antonopoulos, D.A.; Jabri, B.; Chang, E.B. Dietary-fat-induced taurocholic acid promotes pathobiont expansion and colitis in Il10 ${ }^{-/-}$mice. Nature 2012, 487, 104-108. [CrossRef]

33. Chen, M.L.; Takeda, K.; Sundrud, M.S. Emerging roles of bile acids in mucosal immunity and inflammation. Mucosal Immunol. 2019, 12, 851-861. [CrossRef] [PubMed]

34. Sayin, S.I.; Wahlström, A.; Felin, J.; Jäntti, S.; Marschall, H.-U.; Bamberg, K.; Angelin, B.; Hyötyläinen, T.; Orešič, M.; Bäckhed, F. Gut microbiota regulates bile acid metabolism by reducing the levels of tauro-beta-muricholic acid, a naturally occurring FXR antagonist. Cell Metab. 2013, 17, 225-235. [CrossRef]

35. Song, Z.; Cai, Y.; Lao, X.; Wang, X.; Lin, X.; Cui, Y.; Kalavagunta, P.K.; Liao, J.; Jin, L.; Shang, J.; et al. Taxonomic profiling and populational patterns of bacterial bile salt hydrolase (BSH) genes based on worldwide human gut microbiome. Microbiome 2019, 7, 9. [CrossRef]

36. Long, S.L.; Gahan, C.G.M.; Joyce, S.A. Interactions between gut bacteria and bile in health and disease. Mol. Asp. Med. 2017, 56, 54-65. [CrossRef] [PubMed]

37. Weng, Y.J.; Gan, H.Y.; Li, X.; Huang, Y.; Li, Z.C.; Deng, H.M.; Chen, S.Z.; Zhou, Y.; Wang, L.S.; Han, Y.P.; et al. Correlation of diet, microbiota and metabolite networks in inflammatory bowel disease. J. Dig. Dis. 2019, 20, 447-459. [CrossRef]

38. Murakami, M.; Iwamoto, J.; Honda, A.; Tsuji, T.; Tamamushi, M.; Ueda, H.; Monma, T.; Konishi, N.; Yara, S.; Hirayama, T.; et al. Detection of Gut Dysbiosis due to Reduced Clostridium Subcluster XIVa Using the Fecal or Serum Bile Acid Profile. Inflamm. Bowel Dis. 2018, 24, 1035-1044. [CrossRef] [PubMed] 
39. Diederen, K.; Li, J.V.; Donachie, G.E.; de Meij, T.G.; de Waart, D.R.; Hakvoort, T.B.M.; Kindermann, A.; Wagner, J.; Auyeung, V.; Te Velde, A.A.; et al. Exclusive enteral nutrition mediates gut microbial and metabolic changes that are associated with remission in children with Crohn's disease. Sci. Rep. 2020, 10, 18879. [CrossRef]

40. Heinken, A.; Ravcheev, D.A.; Baldini, F.; Heirendt, L.; Fleming, R.M.T.; Thiele, I. Systematic assessment of secondary bile acid metabolism in gut microbes reveals distinct metabolic capabilities in inflammatory bowel disease. Microbiome 2019, 7, 75. [CrossRef]

41. Hernández-Rocha, C.; Borowski, K.; Turpin, W.; Filice, M.; Nayeri, S.; Raygoza Garay, J.A.; Stempak, J.M.; Silverberg, M.S. Integrative analysis of colonic biopsies from inflammatory bowel disease patients identifies an interaction between microbial bile-acid inducible gene abundance and human Angiopoietin-like 4 gene expression. J. Crohn's Colitis 2021. [CrossRef]

42. Hang, S.; Paik, D.; Yao, L.; Kim, E.; Trinath, J.; Lu, J.; Ha, S.; Nelson, B.N.; Kelly, S.P.; Wu, L.; et al. Bile acid metabolites control T17 and T cell differentiation. Nature 2019, 576, 143-148. [CrossRef] [PubMed]

43. Fiorucci, S.; Biagioli, M.; Zampella, A.; Distrutti, E. Bile Acids Activated Receptors Regulate Innate Immunity. Front. Immunol. 2018, 9, 1853. [CrossRef]

44. Xu, M.; Shen, Y.; Cen, M.; Zhu, Y.; Cheng, F.; Tang, L.; Zheng, X.; Kim, J.J.; Dai, N.; Hu, W. Modulation of the Gut MicrobiotaFarnesoid X Receptor Axis Improves Deoxycholic Acid-induced Intestinal Inflammation in Mice. J. Crohn's Colitis 2021. [CrossRef]

45. Islam, K.B.M.S.; Fukiya, S.; Hagio, M.; Fujii, N.; Ishizuka, S.; Ooka, T.; Ogura, Y.; Hayashi, T.; Yokota, A. Bile acid is a host factor that regulates the composition of the cecal microbiota in rats. Gastroenterology 2011, 141, 1773-1781. [CrossRef] [PubMed]

46. Ridlon, J.M.; Alves, J.M.; Hylemon, P.B.; Bajaj, J.S. Cirrhosis, bile acids and gut microbiota: Unraveling a complex relationship. Gut Microbes 2013, 4, 382-387. [CrossRef]

47. Begley, M.; Gahan, C.G.M.; Hill, C. The interaction between bacteria and bile. FEMS Microbiol. Rev. 2005, 29, 625-651. [CrossRef]

48. De Boever, P.; Wouters, R.; Verschaeve, L.; Berckmans, P.; Schoeters, G.; Verstraete, W. Protective effect of the bile salt hydrolaseactive Lactobacillus reuteri against bile salt cytotoxicity. Appl. Microbiol. Biotechnol. 2000, 53, 709-714. [CrossRef] [PubMed]

49. D'Aldebert, E.; Biyeyeme Bi Mve, M.-J.; Mergey, M.; Wendum, D.; Firrincieli, D.; Coilly, A.; Fouassier, L.; Corpechot, C.; Poupon, R.; Housset, C.; et al. Bile salts control the antimicrobial peptide cathelicidin through nuclear receptors in the human biliary epithelium. Gastroenterology 2009, 136, 1435-1443. [CrossRef]

50. Inagaki, T.; Moschetta, A.; Lee, Y.-K.; Peng, L.; Zhao, G.; Downes, M.; Yu, R.T.; Shelton, J.M.; Richardson, J.A.; Repa, J.J.; et al. Regulation of antibacterial defense in the small intestine by the nuclear bile acid receptor. Proc. Natl. Acad. Sci. USA 2006, 103, 3920-3925. [CrossRef]

51. Li, T.; Chiang, J.Y.L. Bile acid signaling in metabolic disease and drug therapy. Pharm. Rev. 2014, 66, 948-983. [CrossRef]

52. Postler, T.S.; Ghosh, S. Understanding the Holobiont: How Microbial Metabolites Affect Human Health and Shape the Immune System. Cell Metab. 2017, 26, 110-130. [CrossRef]

53. Fiorucci, S.; Distrutti, E. Bile Acid-Activated Receptors, Intestinal Microbiota, and the Treatment of Metabolic Disorders. Trends Mol. Med. 2015, 21, 702-714. [CrossRef]

54. Li, F.; Jiang, C.; Krausz, K.W.; Li, Y.; Albert, I.; Hao, H.; Fabre, K.M.; Mitchell, J.B.; Patterson, A.D.; Gonzalez, F.J. Microbiome remodelling leads to inhibition of intestinal farnesoid $X$ receptor signalling and decreased obesity. Nat. Commun. 2013, 4, 2384. [CrossRef]

55. Manichanh, C.; Rigottier-Gois, L.; Bonnaud, E.; Gloux, K.; Pelletier, E.; Frangeul, L.; Nalin, R.; Jarrin, C.; Chardon, P.; Marteau, P.; et al. Reduced diversity of faecal microbiota in Crohn's disease revealed by a metagenomic approach. Gut 2006, 55, 205-211. [CrossRef]

56. Zhang, L.; Xie, C.; Nichols, R.G.; Chan, S.H.J.; Jiang, C.; Hao, R.; Smith, P.B.; Cai, J.; Simons, M.N.; Hatzakis, E.; et al. Farnesoid X Receptor Signaling Shapes the Gut Microbiota and Controls Hepatic Lipid Metabolism. mSystems 2016, 1, e00070-16. [CrossRef] [PubMed]

57. Gadaleta, R.M.; van Erpecum, K.J.; Oldenburg, B.; Willemsen, E.C.; Renooij, W.; Murzilli, S.; Klomp, L.W.; Siersema, P.D.; Schipper, M.E.; Danese, S.; et al. Farnesoid X receptor activation inhibits inflammation and preserves the intestinal barrier in inflammatory bowel disease. Gut 2011, 60, 463-472. [CrossRef]

58. Vavassori, P.; Mencarelli, A.; Renga, B.; Distrutti, E.; Fiorucci, S. The bile acid receptor FXR is a modulator of intestinal innate immunity. J. Immunol. 2009, 183, 6251-6261. [CrossRef] [PubMed]

59. Gadaleta, R.M.; van Mil, S.W.C.; Oldenburg, B.; Siersema, P.D.; Klomp, L.W.J.; van Erpecum, K.J. Bile acids and their nuclear receptor FXR: Relevance for hepatobiliary and gastrointestinal disease. Biochim. Biophys. Acta 2010, 1801, 683-692. [CrossRef] [PubMed]

60. Gadaleta, R.M.; Garcia-Irigoyen, O.; Cariello, M.; Scialpi, N.; Peres, C.; Vetrano, S.; Fiorino, G.; Danese, S.; Ko, B.; Luo, J.; et al. Fibroblast Growth Factor 19 modulates intestinal microbiota and inflammation in presence of Farnesoid X Receptor. EBioMedicine 2020, 54, 102719. [CrossRef]

61. Duboc, H.; Taché, Y.; Hofmann, A.F. The bile acid TGR5 membrane receptor: From basic research to clinical application. Dig. Liver Dis. 2014, 46, 302-312. [CrossRef]

62. Cipriani, S.; Mencarelli, A.; Chini, M.G.; Distrutti, E.; Renga, B.; Bifulco, G.; Baldelli, F.; Donini, A.; Fiorucci, S. The bile acid receptor GPBAR-1 (TGR5) modulates integrity of intestinal barrier and immune response to experimental colitis. PLoS ONE 2011, 6, e25637. [CrossRef] 
63. Calmus, Y.; Poupon, R. Shaping macrophages function and innate immunity by bile acids: Mechanisms and implication in cholestatic liver diseases. Clin. Res. Hepatol. Gastroenterol. 2014, 38, 550-556. [CrossRef] [PubMed]

64. Sun, M.; He, C.; Cong, Y.; Liu, Z. Regulatory immune cells in regulation of intestinal inflammatory response to microbiota. Mucosal Immunol. 2015, 8, 969-978. [CrossRef]

65. Mosser, D.M.; Edwards, J.P. Exploring the full spectrum of macrophage activation. Nat. Rev. Immunol. 2008, 8, 958-969. [CrossRef]

66. Haselow, K.; Bode, J.G.; Wammers, M.; Ehlting, C.; Keitel, V.; Kleinebrecht, L.; Schupp, A.-K.; Häussinger, D.; Graf, D. Bile acids PKA-dependently induce a switch of the IL-10/IL-12 ratio and reduce proinflammatory capability of human macrophages. J. Leukoc. Biol. 2013, 94, 1253-1264. [CrossRef] [PubMed]

67. Yoneno, K.; Hisamatsu, T.; Shimamura, K.; Kamada, N.; Ichikawa, R.; Kitazume, M.T.; Mori, M.; Uo, M.; Namikawa, Y.; Matsuoka, K.; et al. TGR5 signalling inhibits the production of pro-inflammatory cytokines by in vitro differentiated inflammatory and intestinal macrophages in Crohn's disease. Immunology 2013, 139, 19-29. [CrossRef]

68. Ichikawa, R.; Takayama, T.; Yoneno, K.; Kamada, N.; Kitazume, M.T.; Higuchi, H.; Matsuoka, K.; Watanabe, M.; Itoh, H.; Kanai, T.; et al. Bile acids induce monocyte differentiation toward interleukin-12 hypo-producing dendritic cells via a TGR5dependent pathway. Immunology 2012, 136, 153-162. [CrossRef] [PubMed]

69. Guo, C.; Xie, S.; Chi, Z.; Zhang, J.; Liu, Y.; Zhang, L.; Zheng, M.; Zhang, X.; Xia, D.; Ke, Y.; et al. Bile Acids Control Inflammation and Metabolic Disorder through Inhibition of NLRP3 Inflammasome. Immunity 2016, 45, 802-816. [CrossRef]

70. Oladimeji, P.O.; Chen, T. PXR: More Than Just a Master Xenobiotic Receptor. Mol. Pharm. 2018, 93, 119-127. [CrossRef]

71. Dempsey, J.L.; Wang, D.; Siginir, G.; Fei, Q.; Raftery, D.; Gu, H.; Yue Cui, J. Pharmacological Activation of PXR and CAR Downregulates Distinct Bile Acid-Metabolizing Intestinal Bacteria and Alters Bile Acid Homeostasis. Toxicol. Sci. 2019, 168, 40-60. [CrossRef]

72. Caparrós-Martín, J.A.; Lareu, R.R.; Ramsay, J.P.; Peplies, J.; Reen, F.J.; Headlam, H.A.; Ward, N.C.; Croft, K.D.; Newsholme, P.; Hughes, J.D.; et al. Statin therapy causes gut dysbiosis in mice through a PXR-dependent mechanism. Microbiome 2017, 5, 95. [CrossRef]

73. Venkatesh, M.; Mukherjee, S.; Wang, H.; Li, H.; Sun, K.; Benechet, A.P.; Qiu, Z.; Maher, L.; Redinbo, M.R.; Phillips, R.S.; et al. Symbiotic bacterial metabolites regulate gastrointestinal barrier function via the xenobiotic sensor PXR and Toll-like receptor 4 . Immunity 2014, 41, 296-310. [CrossRef] [PubMed]

74. Langmann, T.; Moehle, C.; Mauerer, R.; Scharl, M.; Liebisch, G.; Zahn, A.; Stremmel, W.; Schmitz, G. Loss of detoxification in inflammatory bowel disease: Dysregulation of pregnane X receptor target genes. Gastroenterology 2004, 127, 26-40. [CrossRef] [PubMed]

75. Glas, J.; Seiderer, J.; Fischer, D.; Tengler, B.; Pfennig, S.; Wetzke, M.; Beigel, F.; Olszak, T.; Weidinger, M.; Göke, B.; et al. Pregnane $\mathrm{X}$ receptor (PXR/NR1I2) gene haplotypes modulate susceptibility to inflammatory bowel disease. Inflamm. Bowel Dis. 2011, 17, 1917-1924. [CrossRef] [PubMed]

76. Martínez, A.; Márquez, A.; Mendoza, J.; Taxonera, C.; Fernández-Arquero, M.; Díaz-Rubio, M.; de la Concha, E.G.; Urcelay, E. Role of the PXR gene locus in inflammatory bowel diseases. Inflamm. Bowel Dis. 2007, 13, 1484-1487. [CrossRef]

77. Shah, Y.M.; Ma, X.; Morimura, K.; Kim, I.; Gonzalez, F.J. Pregnane X receptor activation ameliorates DSS-induced inflammatory bowel disease via inhibition of NF-kappaB target gene expression. Am. J. Physiol. Gastrointest. Liver Physiol. 2007, 292, G1114-G1122. [CrossRef]

78. Zhou, C.; Tabb, M.M.; Nelson, E.L.; Grün, F.; Verma, S.; Sadatrafiei, A.; Lin, M.; Mallick, S.; Forman, B.M.; Thummel, K.E.; et al. Mutual repression between steroid and xenobiotic receptor and NF-kappaB signaling pathways links xenobiotic metabolism and inflammation. J. Clin. Investig. 2006, 116, 2280-2289. [CrossRef]

79. Makishima, M.; Lu, T.T.; Xie, W.; Whitfield, G.K.; Domoto, H.; Evans, R.M.; Haussler, M.R.; Mangelsdorf, D.J. Vitamin D receptor as an intestinal bile acid sensor. Science 2002, 296, 1313-1316. [CrossRef] [PubMed]

80. Wang, J.; Thingholm, L.B.; Skiecevičienè, J.; Rausch, P.; Kummen, M.; Hov, J.R.; Degenhardt, F.; Heinsen, F.-A.; Rühlemann, M.C.; Szymczak, S.; et al. Genome-wide association analysis identifies variation in vitamin D receptor and other host factors influencing the gut microbiota. Nat. Genet. 2016, 48, 1396-1406. [CrossRef]

81. Simmons, J.D.; Mullighan, C.; Welsh, K.I.; Jewell, D.P. Vitamin D receptor gene polymorphism: Association with Crohn's disease susceptibility. Gut 2000, 47, 211-214. [CrossRef]

82. Liu, W.; Chen, Y.; Golan, M.A.; Annunziata, M.L.; Du, J.; Dougherty, U.; Kong, J.; Musch, M.; Huang, Y.; Pekow, J.; et al. Intestinal epithelial vitamin D receptor signaling inhibits experimental colitis. J. Clin. Investig. 2013, 123, 3983-3996. [CrossRef]

83. Garg, M.; Royce, S.G.; Tikellis, C.; Shallue, C.; Sluka, P.; Wardan, H.; Hosking, P.; Monagle, S.; Thomas, M.; Lubel, J.S.; et al. The intestinal vitamin D receptor in inflammatory bowel disease: Inverse correlation with inflammation but no relationship with circulating vitamin D status. Ther. Adv. Gastroenterol. 2019, 12, 1756284818822566. [CrossRef]

84. He, L.; Liu, T.; Shi, Y.; Tian, F.; Hu, H.; Deb, D.K.; Chen, Y.; Bissonnette, M.; Li, Y.C. Gut Epithelial Vitamin D Receptor Regulates Microbiota-Dependent Mucosal Inflammation by Suppressing Intestinal Epithelial Cell Apoptosis. Endocrinology 2018, 159, 967-979. [CrossRef] [PubMed]

85. Vaishnava, S.; Behrendt, C.L.; Ismail, A.S.; Eckmann, L.; Hooper, L.V. Paneth cells directly sense gut commensals and maintain homeostasis at the intestinal host-microbial interface. Proc. Natl. Acad. Sci. USA 2008, 105, 20858-20863. [CrossRef] 
86. Lu, R.; Zhang, Y.-G.; Xia, Y.; Sun, J. Imbalance of autophagy and apoptosis in intestinal epithelium lacking the vitamin D receptor. FASEB J. 2019, 33, 11845-11856. [CrossRef]

87. Wu, S.; Zhang, Y.-G.; Lu, R.; Xia, Y.; Zhou, D.; Petrof, E.O.; Claud, E.C.; Chen, D.; Chang, E.B.; Carmeliet, G.; et al. Intestinal epithelial vitamin D receptor deletion leads to defective autophagy in colitis. Gut 2015, 64, 1082-1094. [CrossRef] [PubMed]

88. Paramsothy, S.; Nielsen, S.; Kamm, M.A.; Deshpande, N.P.; Faith, J.J.; Clemente, J.C.; Paramsothy, R.; Walsh, A.J.; van den Bogaerde, J.; Samuel, D.; et al. Specific Bacteria and Metabolites Associated with Response to Fecal Microbiota Transplantation in Patients with Ulcerative Colitis. Gastroenterology 2019, 156, 1440-1454. [CrossRef] [PubMed]

89. Wang, S.; Martins, R.; Sullivan, M.C.; Friedman, E.S.; Misic, A.M.; El-Fahmawi, A.; De Martinis, E.C.P.; O’Brien, K.; Chen, Y.; Bradley, C.; et al. Diet-induced remission in chronic enteropathy is associated with altered microbial community structure and synthesis of secondary bile acids. Microbiome 2019, 7, 126. [CrossRef]

90. Ke, J.; Li, Y.; Han, C.; He, R.; Lin, R.; Qian, W.; Hou, X. Fucose Ameliorate Intestinal Inflammation Through Modulating the Crosstalk Between Bile Acids and Gut Microbiota in a Chronic Colitis Murine Model. Inflamm. Bowel Dis. 2020, 26, 863-873. [CrossRef] [PubMed]

91. Jia, Y.-Q.; Yuan, Z.-W.; Zhang, X.-S.; Dong, J.-Q.; Liu, X.-N.; Peng, X.-T.; Yao, W.-L.; Ji, P.; Wei, Y.-M.; Hua, Y.-L. Total alkaloids of Sophora alopecuroides L. ameliorated murine colitis by regulating bile acid metabolism and gut microbiota. J. Ethnopharmacol. 2020, 255, 112775. [CrossRef] [PubMed]

92. Hou, J.K.; Abraham, B.; El-Serag, H. Dietary intake and risk of developing inflammatory bowel disease: A systematic review of the literature. Am. J. Gastroenterol. 2011, 106, 563-573. [CrossRef] [PubMed]

93. Wan, Y.; Yuan, J.; Li, J.; Li, H.; Zhang, J.; Tang, J.; Ni, Y.; Huang, T.; Wang, F.; Zhao, F.; et al. Unconjugated and secondary bile acid profiles in response to higher-fat, lower-carbohydrate diet and associated with related gut microbiota: A 6-month randomized controlled-feeding trial. Clin. Nutr. 2020, 39, 395-404. [CrossRef] [PubMed]

94. David, L.A.; Maurice, C.F.; Carmody, R.N.; Gootenberg, D.B.; Button, J.E.; Wolfe, B.E.; Ling, A.V.; Devlin, A.S.; Varma, Y.; Fischbach, M.A.; et al. Diet rapidly and reproducibly alters the human gut microbiome. Nature 2014, 505, 559-563. [CrossRef]

95. Llewellyn, S.R.; Britton, G.J.; Contijoch, E.J.; Vennaro, O.H.; Mortha, A.; Colombel, J.-F.; Grinspan, A.; Clemente, J.C.; Merad, M.; Faith, J.J. Interactions Between Diet and the Intestinal Microbiota Alter Intestinal Permeability and Colitis Severity in Mice. Gastroenterology 2018, 154. [CrossRef] [PubMed]

96. Bischoff, S.C.; Escher, J.; Hébuterne, X.; Kłęk, S.; Krznaric, Z.; Schneider, S.; Shamir, R.; Stardelova, K.; Wierdsma, N.; Wiskin, A.E.; et al. ESPEN practical guideline: Clinical Nutrition in inflammatory bowel disease. Clin. Nutr. 2020, 39, 632-653. [CrossRef] [PubMed]

97. Ruemmele, F.M.; Veres, G.; Kolho, K.L.; Griffiths, A.; Levine, A.; Escher, J.C.; Amil Dias, J.; Barabino, A.; Braegger, C.P.; Bronsky, J.; et al. Consensus guidelines of ECCO/ESPGHAN on the medical management of pediatric Crohn's disease. J. Crohn's Colitis 2014, 8, 1179-1207. [CrossRef] [PubMed]

98. Ashton, J.J.; Gavin, J.; Beattie, R.M. Exclusive enteral nutrition in Crohn's disease: Evidence and practicalities. Clin. Nutr. 2019, 38, 80-89. [CrossRef]

99. Hansen, T.; Duerksen, D.R. Enteral Nutrition in the Management of Pediatric and Adult Crohn's Disease. Nutrients 2018, 10, 537. [CrossRef]

100. Leach, S.T.; Mitchell, H.M.; Eng, W.R.; Zhang, L.; Day, A.S. Sustained modulation of intestinal bacteria by exclusive enteral nutrition used to treat children with Crohn's disease. Aliment. Pharmacol. Ther. 2008, 28, 724-733. [CrossRef] [PubMed]

101. Quince, C.; Ijaz, U.Z.; Loman, N.; Eren, A.M.; Saulnier, D.; Russell, J.; Haig, S.J.; Calus, S.T.; Quick, J.; Barclay, A.; et al. Extensive Modulation of the Fecal Metagenome in Children With Crohn's Disease During Exclusive Enteral Nutrition. Am. J. Gastroenterol. 2015, 110, 1718. [CrossRef] [PubMed]

102. Connors, J.; Dunn, K.A.; Allott, J.; Bandsma, R.; Rashid, M.; Otley, A.R.; Bielawski, J.P.; Van Limbergen, J. The relationship between fecal bile acids and microbiome community structure in pediatric Crohn's disease. ISME J. 2020, 14, 702-713. [CrossRef] [PubMed]

103. Tsertsvadze, A.; Gurung, T.; Court, R.; Clarke, A.; Sutcliffe, P. Clinical effectiveness and cost-effectiveness of elemental nutrition for the maintenance of remission in Crohn's disease: A systematic review and meta-analysis. Health Technol. Assess. 2015, 19, 1-138. [CrossRef] [PubMed]

104. Sartor, R.B.; Wu, G.D. Roles for Intestinal Bacteria, Viruses, and Fungi in Pathogenesis of Inflammatory Bowel Diseases and Therapeutic Approaches. Gastroenterology 2017, 152, 327-339. [CrossRef]

105. Gareau, M.G.; Sherman, P.M.; Walker, W.A. Probiotics and the gut microbiota in intestinal health and disease. Nat. Rev. Gastroenterol. Hepatol. 2010, 7, 503-514. [CrossRef]

106. Kruis, W.; Fric, P.; Pokrotnieks, J.; Lukás, M.; Fixa, B.; Kascák, M.; Kamm, M.A.; Weismueller, J.; Beglinger, C.; Stolte, M.; et al. Maintaining remission of ulcerative colitis with the probiotic Escherichia coli Nissle 1917 is as effective as with standard mesalazine. Gut 2004, 53, 1617-1623. [CrossRef]

107. Rembacken, B.J.; Snelling, A.M.; Hawkey, P.M.; Chalmers, D.M.; Axon, A.T. Non-pathogenic Escherichia coli versus mesalazine for the treatment of ulcerative colitis: A randomised trial. Lancet 1999, 354, 635-639. [CrossRef]

108. Kruis, W.; Schütz, E.; Fric, P.; Fixa, B.; Judmaier, G.; Stolte, M. Double-blind comparison of an oral Escherichia coli preparation and mesalazine in maintaining remission of ulcerative colitis. Aliment. Pharmacol. Ther. 1997, 11, 853-858. [CrossRef] 
109. Kato, K.; Mizuno, S.; Umesaki, Y.; Ishii, Y.; Sugitani, M.; Imaoka, A.; Otsuka, M.; Hasunuma, O.; Kurihara, R.; Iwasaki, A.; et al. Randomized placebo-controlled trial assessing the effect of bifidobacteria-fermented milk on active ulcerative colitis. Aliment. Pharmacol. Ther. 2004, 20, 1133-1141. [CrossRef]

110. Zocco, M.A.; dal Verme, L.Z.; Cremonini, F.; Piscaglia, A.C.; Nista, E.C.; Candelli, M.; Novi, M.; Rigante, D.; Cazzato, I.A.; Ojetti, V.; et al. Efficacy of Lactobacillus GG in maintaining remission of ulcerative colitis. Aliment. Pharmacol. Ther. 2006, 23, 1567-1574. [CrossRef]

111. Oliva, S.; Di Nardo, G.; Ferrari, F.; Mallardo, S.; Rossi, P.; Patrizi, G.; Cucchiara, S.; Stronati, L. Randomised clinical trial: The effectiveness of Lactobacillus reuteri ATCC 55730 rectal enema in children with active distal ulcerative colitis. Aliment. Pharmacol. Ther. 2012, 35, 327-334. [CrossRef] [PubMed]

112. Tursi, A.; Brandimarte, G.; Papa, A.; Giglio, A.; Elisei, W.; Giorgetti, G.M.; Forti, G.; Morini, S.; Hassan, C.; Pistoia, M.A.; et al. Treatment of relapsing mild-to-moderate ulcerative colitis with the probiotic VSL\#3 as adjunctive to a standard pharmaceutical treatment: A double-blind, randomized, placebo-controlled study. Am. J. Gastroenterol. 2010, 105, 2218-2227. [CrossRef] [PubMed]

113. Miele, E.; Pascarella, F.; Giannetti, E.; Quaglietta, L.; Baldassano, R.N.; Staiano, A. Effect of a probiotic preparation (VSL\#3) on induction and maintenance of remission in children with ulcerative colitis. Am. J. Gastroenterol. 2009, 104, 437-443. [CrossRef] [PubMed]

114. Saez-Lara, M.J.; Gomez-Llorente, C.; Plaza-Diaz, J.; Gil, A. The role of probiotic lactic acid bacteria and bifidobacteria in the prevention and treatment of inflammatory bowel disease and other related diseases: A systematic review of randomized human clinical trials. Biomed. Res. Int. 2015, 2015, 505878. [CrossRef]

115. Madsen, K.; Cornish, A.; Soper, P.; McKaigney, C.; Jijon, H.; Yachimec, C.; Doyle, J.; Jewell, L.; De Simone, C. Probiotic bacteria enhance murine and human intestinal epithelial barrier function. Gastroenterology 2001, 121, 580-591. [CrossRef]

116. Chapman, T.M.; Plosker, G.L.; Figgitt, D.P. VSL\#3 probiotic mixture: A review of its use in chronic inflammatory bowel diseases. Drugs 2006, 66, 1371-1387.

117. Martoni, C.J.; Labbé, A.; Ganopolsky, J.G.; Prakash, S.; Jones, M.L. Changes in bile acids, FGF-19 and sterol absorption in response to bile salt hydrolase active L. reuteri NCIMB 30242. Gut Microbes 2015, 6, 57-65. [CrossRef]

118. Zhai, Q.; Liu, Y.; Wang, C.; Qu, D.; Zhao, J.; Zhang, H.; Tian, F.; Chen, W. Lactobacillus plantarum CCFM8661 modulates bile acid enterohepatic circulation and increases lead excretion in mice. Food Funct. 2019, 10, 1455-1464. [CrossRef]

119. Degirolamo, C.; Rainaldi, S.; Bovenga, F.; Murzilli, S.; Moschetta, A. Microbiota modification with probiotics induces hepatic bile acid synthesis via downregulation of the Fxr-Fgf15 axis in mice. Cell Rep. 2014, 7, 12-18. [CrossRef]

120. Bourreille, A.; Cadiot, G.; Le Dreau, G.; Laharie, D.; Beaugerie, L.; Dupas, J.-L.; Marteau, P.; Rampal, P.; Moyse, D.; Saleh, A.; et al. Saccharomyces boulardii does not prevent relapse of Crohn's disease. Clin. Gastroenterol. Hepatol. Off. Clin. Pract. J. Am. Gastroenterol. Assoc. 2013, 11, 982-987. [CrossRef]

121. Bjarnason, I.; Sission, G.; Hayee, B.H. A randomised, double-blind, placebo-controlled trial of a multi-strain probiotic in patients with asymptomatic ulcerative colitis and Crohn's disease. Inflammopharmacology 2019, 27, 465-473. [CrossRef]

122. Ganji-Arjenaki, M.; Rafieian-Kopaei, M. Probiotics are a good choice in remission of inflammatory bowel diseases: A meta analysis and systematic review. J. Cell. Physiol. 2018, 233, 2091-2103. [CrossRef]

123. van der Lelie, D.; Oka, A.; Taghavi, S.; Umeno, J.; Fan, T.-J.; Merrell, K.E.; Watson, S.D.; Ouellette, L.; Liu, B.; Awoniyi, M.; et al. Rationally designed bacterial consortia to treat chronic immune-mediated colitis and restore intestinal homeostasis. Nat. Commun. 2021, 12, 3105. [CrossRef] [PubMed]

124. Gibson, G.R.; Hutkins, R.; Sanders, M.E.; Prescott, S.L.; Reimer, R.A.; Salminen, S.J.; Scott, K.; Stanton, C.; Swanson, K.S.; Cani, P.D.; et al. Expert consensus document: The International Scientific Association for Probiotics and Prebiotics (ISAPP) consensus statement on the definition and scope of prebiotics. Nat. Rev. Gastroenterol. Hepatol. 2017, 14, 491-502. [CrossRef]

125. Casellas, F.; Borruel, N.; Torrejón, A.; Varela, E.; Antolin, M.; Guarner, F.; Malagelada, J.R. Oral oligofructose-enriched inulin supplementation in acute ulcerative colitis is well tolerated and associated with lowered faecal calprotectin. Aliment. Pharmacol. Ther. 2007, 25, 1061-1067. [CrossRef] [PubMed]

126. Valcheva, R.; Koleva, P.; Martínez, I.; Walter, J.; Gänzle, M.G.; Dieleman, L.A. Inulin-type fructans improve active ulcerative colitis associated with microbiota changes and increased short-chain fatty acids levels. Gut Microbes 2019, 10, 334-357. [CrossRef] [PubMed]

127. Vandeputte, D.; Falony, G.; Vieira-Silva, S.; Wang, J.; Sailer, M.; Theis, S.; Verbeke, K.; Raes, J. Prebiotic inulin-type fructans induce specific changes in the human gut microbiota. Gut 2017, 66, 1968-1974. [CrossRef]

128. Scott, K.P.; Martin, J.C.; Duncan, S.H.; Flint, H.J. Prebiotic stimulation of human colonic butyrate-producing bacteria and bifidobacteria, in vitro. FEMS Microbiol. Ecol. 2014, 87, 30-40. [CrossRef]

129. Alexander, C.; Cross, T.-W.L.; Devendran, S.; Neumer, F.; Theis, S.; Ridlon, J.M.; Suchodolski, J.S.; de Godoy, M.R.C.; Swanson, K.S. Effects of prebiotic inulin-type fructans on blood metabolite and hormone concentrations and faecal microbiota and metabolites in overweight dogs. Br. J. Nutr. 2018, 120,711-720. [CrossRef]

130. Steidler, L.; Hans, W.; Schotte, L.; Neirynck, S.; Obermeier, F.; Falk, W.; Fiers, W.; Remaut, E. Treatment of murine colitis by Lactococcus lactis secreting interleukin-10. Science 2000, 289, 1352-1355. [CrossRef]

131. Hanson, M.L.; Hixon, J.A.; Li, W.; Felber, B.K.; Anver, M.R.; Stewart, C.A.; Janelsins, B.M.; Datta, S.K.; Shen, W.; McLean, M.H.; et al. Oral delivery of IL-27 recombinant bacteria attenuates immune colitis in mice. Gastroenterology 2014, 146, 210-221. [CrossRef] [PubMed] 
132. Praveschotinunt, P.; Duraj-Thatte, A.M.; Gelfat, I.; Bahl, F.; Chou, D.B.; Joshi, N.S. Engineered E. coli Nissle 1917 for the delivery of matrix-tethered therapeutic domains to the gut. Nat. Commun. 2019, 10, 5580. [CrossRef] [PubMed]

133. Vandenbroucke, K.; Hans, W.; Van Huysse, J.; Neirynck, S.; Demetter, P.; Remaut, E.; Rottiers, P.; Steidler, L. Active delivery of trefoil factors by genetically modified Lactococcus lactis prevents and heals acute colitis in mice. Gastroenterology 2004, 127, 502-513. [CrossRef]

134. Campbell, C.; McKenney, P.T.; Konstantinovsky, D.; Isaeva, O.I.; Schizas, M.; Verter, J.; Mai, C.; Jin, W.-B.; Guo, C.-J.; Violante, S.; et al. Bacterial metabolism of bile acids promotes generation of peripheral regulatory T cells. Nature 2020, 581, 475-479. [CrossRef] [PubMed]

135. Allegretti, J.R.; Mullish, B.H.; Kelly, C.; Fischer, M. The evolution of the use of faecal microbiota transplantation and emerging therapeutic indications. Lancet 2019, 394, 420-431. [CrossRef]

136. Khoruts, A.; Sadowsky, M.J. Understanding the mechanisms of faecal microbiota transplantation. Nat. Rev. Gastroenterol. Hepatol. 2016, 13, 508-516. [CrossRef]

137. Weingarden, A.; González, A.; Vázquez-Baeza, Y.; Weiss, S.; Humphry, G.; Berg-Lyons, D.; Knights, D.; Unno, T.; Bobr, A.; Kang, J.; et al. Dynamic changes in short- and long-term bacterial composition following fecal microbiota transplantation for recurrent Clostridium difficile infection. Microbiome 2015, 3, 10. [CrossRef]

138. Bojanova, D.P.; Bordenstein, S.R. Fecal Transplants: What Is Being Transferred? PLoS Biol. 2016, 14, e1002503. [CrossRef]

139. Ng, S.C.; Kamm, M.A.; Yeoh, Y.K.; Chan, P.K.S.; Zuo, T.; Tang, W.; Sood, A.; Andoh, A.; Ohmiya, N.; Zhou, Y.; et al. Scientific frontiers in faecal microbiota transplantation: Joint document of Asia-Pacific Association of Gastroenterology (APAGE) and Asia-Pacific Society for Digestive Endoscopy (APSDE). Gut 2020, 69, 83-91. [CrossRef] [PubMed]

140. Costello, S.; Waters, O.; Bryant, R.; Katsikeros, R.; Makanyanga, J.; Schoeman, M.; Mountifield, R.; Tee, D.; Howell, S.; Hughes, P.; et al. OP036 Short duration, low intensity pooled faecal microbiota transplantation induces remission in patients with mild-moderately active ulcerative colitis: A randomised controlled trial. J. Crohn's Colitis 2017, 11, S23. [CrossRef]

141. Paramsothy, S.; Kamm, M.A.; Kaakoush, N.O.; Walsh, A.J.; van den Bogaerde, J.; Samuel, D.; Leong, R.W.L.; Connor, S.; $\mathrm{Ng}$, W.; Paramsothy, R.; et al. Multidonor intensive faecal microbiota transplantation for active ulcerative colitis: A randomised placebo-controlled trial. Lancet 2017, 389, 1218-1228. [CrossRef]

142. Costello, S.P.; Hughes, P.A.; Waters, O.; Bryant, R.V.; Vincent, A.D.; Blatchford, P.; Katsikeros, R.; Makanyanga, J.; Campaniello, M.A.; Mavrangelos, C.; et al. Effect of Fecal Microbiota Transplantation on 8-Week Remission in Patients With Ulcerative Colitis: A Randomized Clinical Trial. JAMA 2019, 321, 156-164. [CrossRef] [PubMed]

143. Sokol, H.; Landman, C.; Seksik, P.; Berard, L.; Montil, M.; Nion-Larmurier, I.; Bourrier, A.; Le Gall, G.; Lalande, V.; De Rougemont, A.; et al. Fecal microbiota transplantation to maintain remission in Crohn's disease: A pilot randomized controlled study. Microbiome 2020, 8, 12. [CrossRef]

144. Cui, B.; Feng, Q.; Wang, H.; Wang, M.; Peng, Z.; Li, P.; Huang, G.; Liu, Z.; Wu, P.; Fan, Z.; et al. Fecal microbiota transplantation through mid-gut for refractory Crohn's disease: Safety, feasibility, and efficacy trial results. J. Gastroenterol. Hepatol. 2015, 30, 51-58. [CrossRef] [PubMed]

145. Imdad, A.; Nicholson, M.R.; Tanner-Smith, E.E.; Zackular, J.P.; Gomez-Duarte, O.G.; Beaulieu, D.B.; Acra, S. Fecal transplantation for treatment of inflammatory bowel disease. Cochrane Database Syst. Rev. 2018, 11, CD012774. [CrossRef] [PubMed]

146. DeFilipp, Z.; Bloom, P.P.; Torres Soto, M.; Mansour, M.K.; Sater, M.R.A.; Huntley, M.H.; Turbett, S.; Chung, R.T.; Chen, Y.-B.; Hohmann, E.L. Drug-Resistant Bacteremia Transmitted by Fecal Microbiota Transplant. N. Engl. J. Med. 2019, 381, 2043-2050. [CrossRef] [PubMed]

147. Hamilton, J.P.; Xie, G.; Raufman, J.-P.; Hogan, S.; Griffin, T.L.; Packard, C.A.; Chatfield, D.A.; Hagey, L.R.; Steinbach, J.H.; Hofmann, A.F. Human cecal bile acids: Concentration and spectrum. Am. J. Physiol. Gastrointest. Liver Physiol. 2007, 293, G256-G263. [CrossRef]

148. Rubin, R.A.; Kowalski, T.E.; Khandelwal, M.; Malet, P.F. Ursodiol for hepatobiliary disorders. Ann. Intern. Med. 1994, 121, 207-218. [CrossRef]

149. Van den Bossche, L.; Borsboom, D.; Devriese, S.; Van Welden, S.; Holvoet, T.; Devisscher, L.; Hindryckx, P.; De Vos, M.; Laukens, D. Tauroursodeoxycholic acid protects bile acid homeostasis under inflammatory conditions and dampens Crohn's disease-like ileitis. Lab. Investig. 2017, 97, 519-529. [CrossRef]

150. Ward, J.B.J.; Lajczak, N.K.; Kelly, O.B.; O’Dwyer, A.M.; Giddam, A.K.; Ní Gabhann, J.; Franco, P.; Tambuwala, M.M.; Jefferies, C.A.; Keely, S.; et al. Ursodeoxycholic acid and lithocholic acid exert anti-inflammatory actions in the colon. Am. J. Physiol. Gastrointest. Liver Physiol. 2017, 312, G550-G558. [CrossRef]

151. Laukens, D.; Devisscher, L.; Van den Bossche, L.; Hindryckx, P.; Vandenbroucke, R.E.; Vandewynckel, Y.-P.; Cuvelier, C.; Brinkman, B.M.; Libert, C.; Vandenabeele, P.; et al. Tauroursodeoxycholic acid inhibits experimental colitis by preventing early intestinal epithelial cell death. Lab. Investig. 2014, 94, 1419-1430. [CrossRef]

152. Pardi, D.S.; Loftus, E.V.; Kremers, W.K.; Keach, J.; Lindor, K.D. Ursodeoxycholic acid as a chemopreventive agent in patients with ulcerative colitis and primary sclerosing cholangitis. Gastroenterology 2003, 124, 889-893. [CrossRef]

153. Pearson, T.; Caporaso, J.G.; Yellowhair, M.; Bokulich, N.A.; Padi, M.; Roe, D.J.; Wertheim, B.C.; Linhart, M.; Martinez, J.A.; Bilagody, C.; et al. Effects of ursodeoxycholic acid on the gut microbiome and colorectal adenoma development. Cancer Med. 2019, 8, 617-628. [CrossRef] 
154. Eaton, J.E.; Silveira, M.G.; Pardi, D.S.; Sinakos, E.; Kowdley, K.V.; Luketic, V.A.C.; Harrison, M.E.; McCashland, T.; Befeler, A.S.; Harnois, D.; et al. High-dose ursodeoxycholic acid is associated with the development of colorectal neoplasia in patients with ulcerative colitis and primary sclerosing cholangitis. Am. J. Gastroenterol. 2011, 106, 1638-1645. [CrossRef]

155. Boonstra, K.; van Erpecum, K.J.; van Nieuwkerk, K.M.J.; Drenth, J.P.H.; Poen, A.C.; Witteman, B.J.M.; Tuynman, H.A.R.E.; Beuers, U.; Ponsioen, C.Y. Primary sclerosing cholangitis is associated with a distinct phenotype of inflammatory bowel disease. Inflamm. Bowel Dis. 2012, 18, 2270-2276. [CrossRef]

156. Quraishi, M.N.; Acharjee, A.; Beggs, A.D.; Horniblow, R.; Tselepis, C.; Gkoutos, G.; Ghosh, S.; Rossiter, A.E.; Loman, N.; van Schaik, W.; et al. A Pilot Integrative Analysis of Colonic Gene Expression, Gut Microbiota, and Immune Infiltration in Primary Sclerosing Cholangitis-Inflammatory Bowel Disease: Association of Disease With Bile Acid Pathways. J. Crohn's Colitis 2020, 14, 935-947. [CrossRef]

157. Dyson, J.K.; Beuers, U.; Jones, D.E.J.; Lohse, A.W.; Hudson, M. Primary sclerosing cholangitis. Lancet 2018, 391, 2547-2559. [CrossRef] 